\title{
Bortezomib enhances the anti-cancer effect of the novel Bruton's tyrosine kinase inhibitor (BGB-3111) in mantle cell lymphoma expressing BTK
}

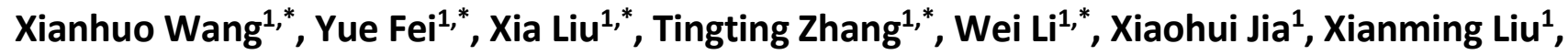 \\ Lihua Qiu' ${ }^{1}$, Zhengzi Qian ${ }^{1}$, Shiyong Zhou ${ }^{1}$, Xiubao Ren $^{2}$, Qiongli Zhai ${ }^{3}$, Bin Meng ${ }^{3}$, Lanfang Li, ${ }^{1, \&}$, \\ Huilai Zhang ${ }^{1, \&}$ \\ ${ }^{1}$ Department of Lymphoma, Tianjin Medical University Cancer Institute and Hospital, National Clinical Research \\ Center of Cancer, Key Laboratory of Cancer Prevention and Therapy, Tianjin's Clinical Research Center for Cancer, \\ The Sino-US Center for Lymphoma and Leukemia Research, Tianjin 300060, China \\ ${ }^{2}$ Department of Biotherapy, Tianjin Medical University Cancer Institute and Hospital, Tianjin 300060, China \\ ${ }^{3}$ Department of Pathology, Tianjin Medical University Cancer Institute and Hospital, Tianjin 300060, China \\ ${ }^{*}$ Co-first authors
}

Correspondence to: Xianhuo Wang, Huilai Zhang, Lanfang Li; email: tjzlyy xianhuow@163.com, https://orcid.org/00000002-7663-2923; zhlwgq@126.com, https://orcid.org/0000-0002-8558-3131; izxqlh@163.com, https://orcid.org/0000$\underline{0003-3030-1739}$

Keywords: BGB-3111, Bruton's tyrosine kinase, bortezomib, mantle cell lymphoma

Received: October 12, $2020 \quad$ Accepted: July 2, $2021 \quad$ Published: September 10, 2021

Copyright: (C) 2021 Wang et al. This is an open access article distributed under the terms of the Creative Commons Attribution License (CC BY 3.0), which permits unrestricted use, distribution, and reproduction in any medium, provided the original author and source are credited.

\section{ABSTRACT}

BGB-3111, a novel Bruton's tyrosine kinase (BTK) inhibitor, shows promising anti-cancer effects in chronic lymphocytic leukemia/small lymphocytic lymphoma (CLL/SLL), mantle cell lymphoma (MCL), and Waldenstrom macroglobulinemia (WM). This study aimed to investigate the anti-cancer effects of BGB-3111 combined with bortezomib (BTZ) against the BTK-expressing MCL. We found that BTK, which was overexpressed in $59.4 \%$ of patients with MCL, was mainly characterized by high Ki67 and elevated MIPI scores. BGB-3111 strongly inhibited cell proliferation, induced cell cycle arrest in the G1/G0-phase, and promoted cell apoptosis in the MCL cells expressing BTK. BGB-3111 provides better safety than another BTK inhibitor, ibrutinib as ibrutinib inhibits the inducible T-cell kinase (ITK) as an off-target effect but BGB-3111 does not inhibit ITK. Low doses of BTZ enhanced the anti-cancer effect induced by the low dose of BGB-3111 by downregulating the expression levels of PARP and $\mathrm{Bcl}-2$ and increasing the expression levels of cleaved PARP and cleaved caspase-9. In addition, low doses of BGB-3111, but not of BTZ, inhibited BTK phosphorylation. However, low-doses of BTZ strengthened the anti-cancer effect induced by the low-doses of BGB-3111 via synergistically suppressing the IKB $\alpha$ and P65 phosphorylation. Taken together, our findings validate that BGB-3111 is a novel and effective BTK inhibitor for MCL-expressing BTK. Hence, it can be harnessed as a potential therapeutic strategy through a combinatorial treatment comprising low-dose BGB-3111 and low-dose BTZ to gain strong anti-cancer effects and better safety for MCL patients.

\section{INTRODUCTION}

Mantle cell lymphoma (MCL) originates from B lymphocytes in the region of the small lymph node, which accounts for $3 \%$ to $10 \%$ of non-Hodgkin's lymphoma (NHL) [1-5]. A majority of MCL patients exhibit an aggressive disease with a poor prognosis $[6,7]$; however, a subset of patients may initially 
exhibit an indolent disease course [8-12]. The genetic characteristics of MCL include $\mathrm{t}(11 ; 14)$ (q13;q32) translocation and cyclin D1 (CCND1) overexpression, which usually causes deregulation of the cell cycle at the G1-S phase transition [13]. Although this translocation is considered to play a primary role in MCL pathogenesis, other carcinogenic events are also required for MCL progression [14-17]. In addition to its pathogenic features, the tissue microenvironment is critical to support MCL cell growth [18].

MCL lymphoma cells are derived from pre-germinal center B-cells and are usually activated by growth factors, which can bind to cell surface receptors. The Bcell receptor (BCR) signaling is crucial for normal Bcell development. It regulates multiple biological processes, including cell proliferation, differentiation, apoptosis, and migration [15, 19]. Bruton's tyrosine kinase (BTK) has been identified as a key component of BCR signaling, which can activate the downstream NF$\kappa \mathrm{B}$ pathway [20]. Ibrutinib is a first-generation BTK inhibitor that can inhibit BTK irreversibly and nonspecifically bind to Cys-481 [19]. Ibrutinib has also become a new standard of care for the treatment of patients with relapsed or refractory chronic lymphocytic leukemia/small lymphocytic lymphoma (CLL/SLL), MCL, and Waldenstrom macroglobulinemia (WM) [21]. However, atrial fibrillation (AF) [22, 23], ventricular arrhythmias [24], and bleeding [25] are emerging as potential threats limiting the desired potential effects. The ibrutinib-induced adverse events may be attributed partly to its off-target effects, involving other kinases, especially the Tec family proteins [26]. In addition, recent reports have demonstrated the possibility of ibrutinib resistance [2731]. Therefore, it is necessary to develop highly specific BTK inhibitors for lymphoma treatment.

BGB-3111 is a novel and next-generation BTK inhibitor, which is designed to selectively target BTK with less off-target activities. Studies have reported that BGB-3111 is less potent in inhibiting rituximab-induced antibody-dependent cellular cytotoxicity compared to ibrutinib [32, 33]. Recent studies have also shown that BGB-3111 has a promising response rate in patients with CLL/SLL, MCL, and WM [34-38]. However, it is still necessary to further study the anti-cancer effects of BGB-3111 and the combination therapy strategies with low-dose BGB-3111 and other targeted agents, which can induce a strong anti-cancer effect with reduced toxicity in MCL.

The NF- $\kappa \mathrm{B}$ signaling plays a key role in the pathogenesis of MCL. NF- $\kappa \mathrm{B}$ regulates the transcription of genes essential for cell survival, proliferation, inflammation, and invasion/metastasis [39]. Bortezomib
(BTZ) has been reported to be a reversible proteasome inhibitor, which could effectively block the activation of the NF- $\mathrm{BB}$ pathway. The development of bortezomib provided a transient response in inducing responses in the relapsed setting; however, these treatments provided moderate responses with toxicities, and the patients eventually recovered [40]. Several trials evaluating bortezomib in combination with other therapeutic agents have also been reported, but the results are disappointing because of the poor response rate and increased treatment-related adverse events [40-46]. A previous study suggested that the proteasome inhibitors suppress NF- $\mathrm{KB}$ activity by stabilizing the inhibitory molecule I $\kappa \mathrm{B}$, which binds $\mathrm{NF}-\kappa \mathrm{B}$ and prevents its nuclear translocation, thereby downregulating the levels of its targets and producing a potent antimyeloma effect [47]. Therefore, BTK inhibitors and proteasome inhibitors play crucial roles in blocking the activation of the NF- $\kappa B$ pathway in different ways. This demonstrated that there may be a synergistic effect between the BTK inhibitor and proteasome inhibitor. In this study, we investigated the anti-cancer effect of BGB-3111 and a combination therapy strategy, in which a low dose of BTZ enhanced the anti-cancer effect of BGB-3111 at a low dose in MCL.

\section{RESULTS}

\section{BTK expression in tissues of MCL patients}

To explore the potential clinical value of BTK inhibitors in MCL patients, we first studied the expression levels of BTK. The baseline characteristics of all patients were as follows: the median age was 61 years (range: $42-75$ years). Of the 32 patients, $23(71.9 \%)$ were male, 9 (28.1\%) were female, $29(90.6 \%)$ were in the advance diseased stage, 23 (71.9\%) were low middle, 9 (28.1\%) were middle-high or high risk, $20(62.5 \%)$ had bone marrow involvement, $16(50 \%)$ had elevated lactate dehydrogenase (LDH) levels, and $14(43.8 \%)$ had elevated beta 2 microglobulin $(\beta 2-\mathrm{M})$ levels. Supplementary Table 1 summarizes the association between the BTK expression and the clinicopathological parameters. Results showed that BTK expression was low in all the benign reactive hyperplasia of lymph nodes and was limited to the germinal center cells of the mantle zone (Figure 1A and 1B). Thirteen $(40.6 \%)$ patients were categorized into the low BTK expression group, which was characterized by less than one-quarter positive staining proportion (Figure 1C and 1D), and 19 (59.4\%) patients were categorized into the high BTK expression group, which was characteristic of a widely broken and disappeared germinal center (Figure 1E and 1F). The correlation analysis between the BTK expression and clinical characteristics revealed that the patients with higher 
BTK levels were always accompanied by high Ki67 (>30\%, $P=0.019)$ and elevated MIPI scores $(P=$ 0.038). Therefore, we found that BTK was overexpressed in the majority of the MCL patients with high Ki67 and MIPI scores, suggesting that the strategy of specifically inhibiting BTK has a promising clinical value for treating MCL.

\section{BGB-3111 inhibits the proliferation in MCL cells expressing BTK}

To evaluate the cell proliferative effect of BGB-3111, we first measured the BTK expression in MCL cell lines. The results revealed that five MCL cell lines had high BTK expression (Figure 2A), out of which three MCL cell lines, including Jeko-1, Rec-1, and Z138, were selected for further studies. Cell growth was detected in the three cell lines treated with increasing doses of BGB-3111 from 0 to $15 \mu \mathrm{M}$ for $48 \mathrm{~h}$ or $72 \mathrm{~h}$. Results showed that BGB-3111 inhibited the cell viability in a dose- and time-dependent manner (Figure 2B). The IC50 values were respectively $9.17 \mu \mathrm{M}, 7.45$ $\mu \mathrm{M}$, and $11.16 \mu \mathrm{M}$ after $48 \mathrm{~h}$ treatment, and were respectively $8.03 \mu \mathrm{M}, 5.61 \mu \mathrm{M}$, and $9.2 \mu \mathrm{M}$ after $72 \mathrm{~h}$ treatment for the Jeko-1, Rec-1, and Z138 cell lines. Our findings showed that BGB-3111 had a strong anticancer effect in the MCL cell lines expressing BTK. Furthermore, after $48 \mathrm{~h}$ treatment with BGB-3111, the subsequent experiments were performed.

\section{BGB-3111 ascends cell-cycle arrest and induces apoptosis in the MCL cells expressing BTK}

Cell cycle analysis was performed to characterize the cytotoxicity of BGB-3111 in the Jeko-1, Rec-1, and Z138 cells. After treatment with BGB-3111 $(0,1,2$, or $3 \mu \mathrm{M}$ ) for $48 \mathrm{~h}$, the cells were arrested in the $\mathrm{G} 1 / \mathrm{G} 0$ phase in a dose-dependent manner, while the percentage of cells in the G2/M phase was significantly reduced (Figure 3 and Supplementary Figure 1). The percentage of $\mathrm{G} 1 / \mathrm{G} 0$ phase cells changed from $33.4 \% \pm 3.01 \%$ to $53.04 \% \pm 6.42 \%, 30.85 \% \pm 2.77 \%$ to $49.89 \% 2.13 \%$, and $27.76 \% \pm 1.53 \%$ to $42.34 \% \pm 3.81 \%$ in the Jeko- 1 , Rec-1, and Z138 cells with the increasing doses of BGB-3111 treatment $(p<0.05)$. Together, our findings suggest that BGB-3111 could induce cell cycle arrest in the G1/G0-phase in the MCL cells.

Furthermore, we determined the cell apoptosis rate in the Jeko-1, Rec-1, and Z138 after treatment with BGB-3111 at increasing doses of $0 \mu \mathrm{M}, 3 \mu \mathrm{M}, 6 \mu \mathrm{M}$, and $9 \mu \mathrm{M}$ for $48 \mathrm{~h}$. Figure 4 and Supplementary Figure 2 show that the apoptosis rate of cells increased from $6.35 \% \pm 0.98 \%$ to $43.25 \% \pm 4.84 \%, 8.79 \% \pm 4.13 \%$ to $61.62 \% \pm 5.64 \%$ and $3.45 \% \pm 0.36 \%$ to $28.84 \% \pm$ $6.23 \%$ in the Jeko-1, Rec-1, and Z138 cells after the BGB-3111 treatment $(p<0.05)$, suggesting that BGB-3111 significantly promotes cellular apoptosis in MCL.
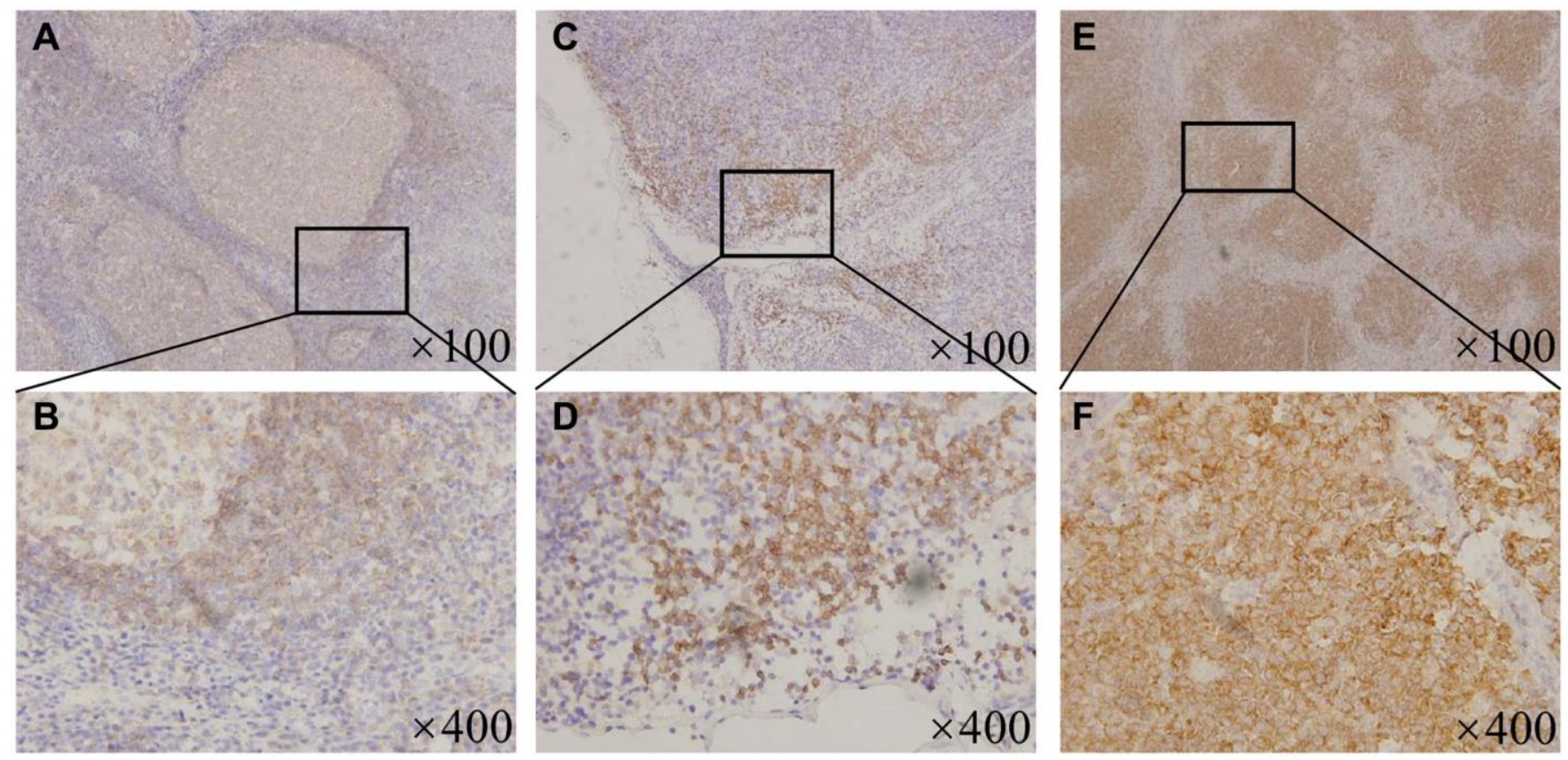

Figure 1. BTK expression in the MCL patients and the benign lymphoid tissues. $(A) \times 100$ magnification and (B) $\times 400$ magnification, Representative patterns of BTK expressing limitedly in the germinal center cells of the mantle zone in the tonsils. (C) $\times 100$ magnification and (D) $\times 400$ magnification, Representative patterns of low BTK expression with less than one-quarter positive staining proportion in the MCL patient tissues. $(E) \times 100$ magnification and $(F) \times 400$ magnification, Representative patterns of high BTK expression with widely broken and disappeared germinal center in the MCL patient tissues. 
A

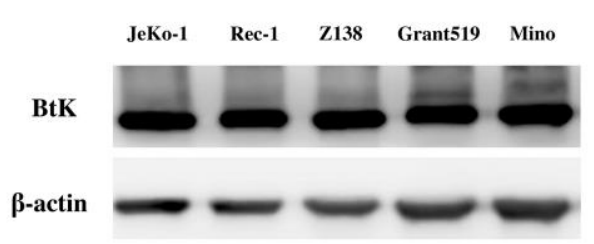

B
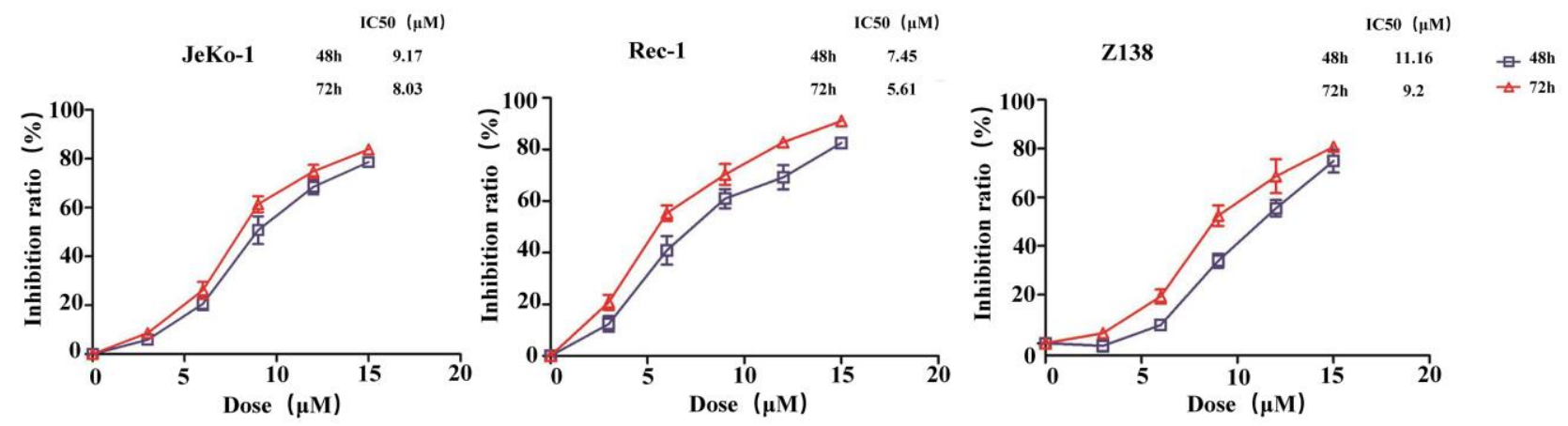

Figure 2. BTK expression in the MCL cell lines and cell viability treated with BGB-3111. (A) The BTK expression in the five MCL cell lines. (B) Cell viability in the Jeko-1, Rec-1, and Z138 treated with BGB-3111 for 48 or $72 \mathrm{~h}$. Results are the mean \pm SD of three independent experiments.
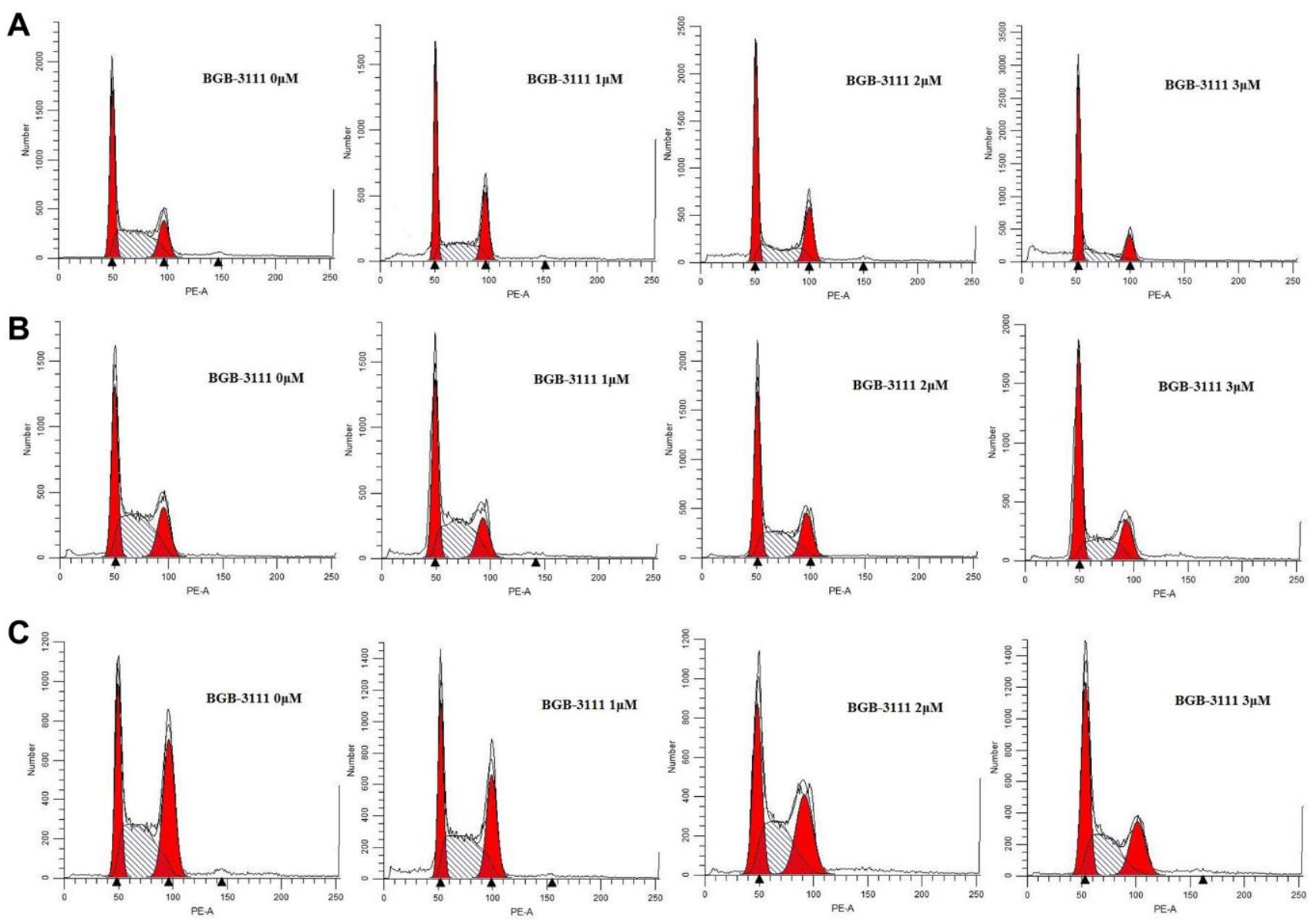

Figure 3. Cell-cycles are arrested at G1/G0-phase in the MCL cell lines after being treated with BGB-3111. Cell cycles of Jeko-1 (A) Rec-1 (B) and Z138 (C) treated with BGB-3111 at the doses of $0 \mu \mathrm{M}, 1 \mu \mathrm{M}, 2 \mu \mathrm{M}$, and $3 \mu \mathrm{M}$ for $48 \mathrm{~h}$. The cell percentage of the cell cycle was detected using flow cytometry. 


\section{ITK expression regulated by BGB-3111 and another BTK inhibitor, ibrutinib in the T-cells}

Ibrutinib was the first BTK inhibitor approved by the FDA for clinical use. However, its adverse events, especially $\mathrm{AF}$, occur in approximately $5 \%$ of $\mathrm{MCL}$ patients. A previous study has shown that ibrutinib has off-target effects, involving the Tec family of proteins, such as the inducible T-cell kinase (ITK) in T-cells through PI3K/AKT signaling [22]. To further characterize this effect of both the drugs in T-cells, we measured the ITK protein in stimulated Jurkat Tcells treated with BGB-3111 or ibrutinib at the same dose of $2 \mu \mathrm{M}$ for $0-48 \mathrm{~h}$. The results showed that after treatment for more than $24 \mathrm{~h}$, the ITK protein was inhibited by ibrutinib, but not with BGB-3111 (Figure 5). These data showed that BGB-3111 is a selective BTK inhibitor and does not inhibit ITK in the T-cells, suggesting that BGB-3111 has the potential to provide better safety in clinical use compared to ibrutinib.
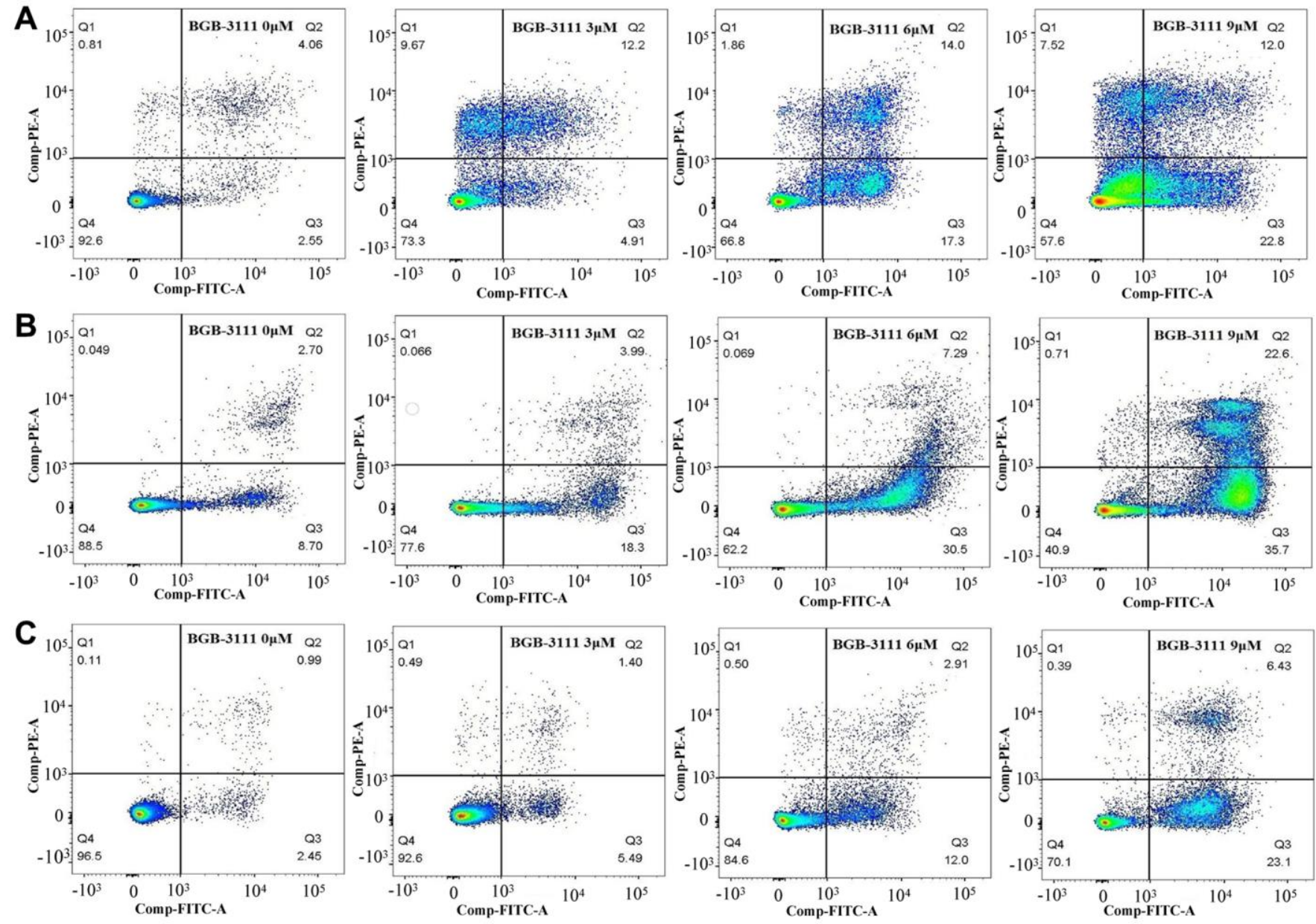

Figure 4. Cell apoptosis in the MCL cell lines after being treated with BGB-3111. The cell apoptosis of Jeko-1 (A) Rec-1 (B) and Z138 (C) treated with BGB-3111 at the doses of $0 \mu \mathrm{M}, 3 \mu \mathrm{M}, 6 \mu \mathrm{M}$, and $9 \mu \mathrm{M}$ for $48 \mathrm{~h}$. The cell apoptotic rate was detected by flow cytometry. 
mediated by the low-dose BGB-3111 in the MCL cells, suggesting that it is a potential therapeutic strategy to combine the low doses of both the drugs to gain effective anti-cancer effects and better safety for MCL.
A

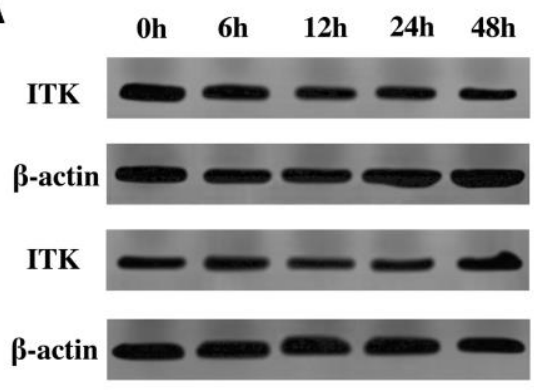

B

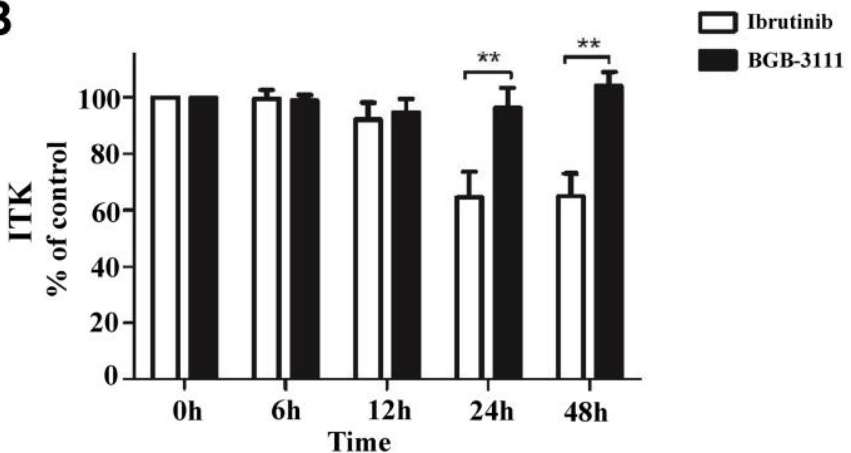

Figure 5. The ITK expression is regulated by BGB-3111 and ibrutinib in the Jurkat T-cells. (A) The ITK expression in the Jurkat T-cells treated with BGB-3111 and ibrutinib at the same dose of $2 \mu \mathrm{M}$ for 0-48 h. (B) The percentage of inhibition rate of the ITK protein in the Jurkat T-cells treated with BGB-3111 and ibrutinib. ${ }^{* *} p<0.01$.

A

IC50 (nM)

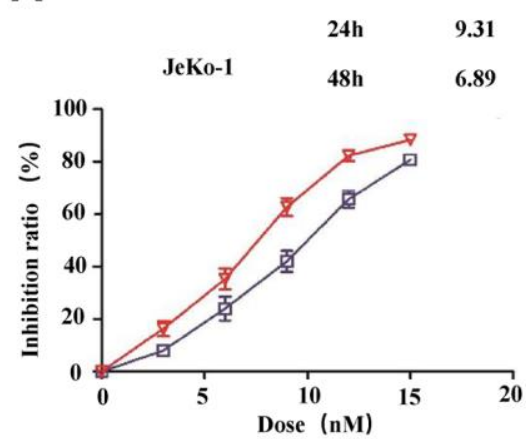

B

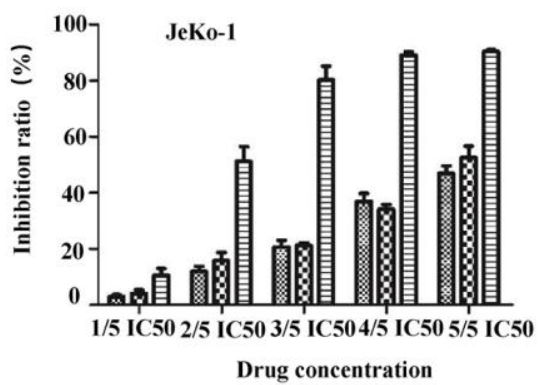

C

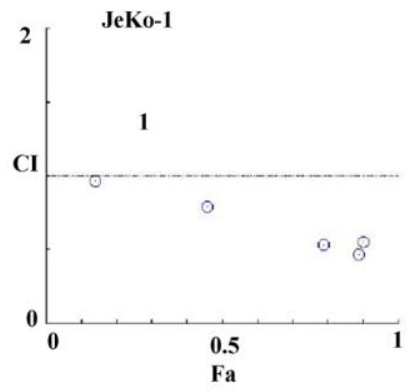

Ibrutinib

BGB-3111

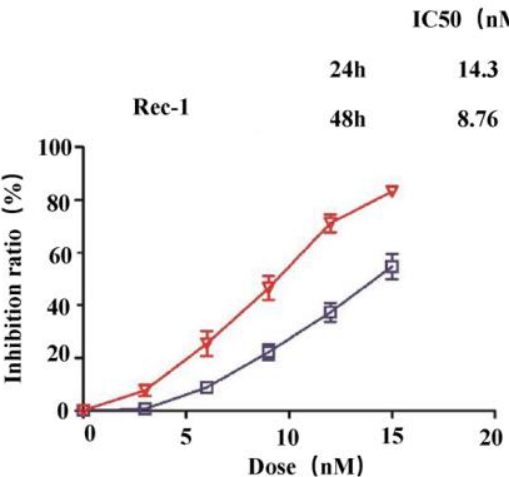

$\mathrm{C50}(\mathrm{nM})$

IC50 ( $\mathrm{nM})$
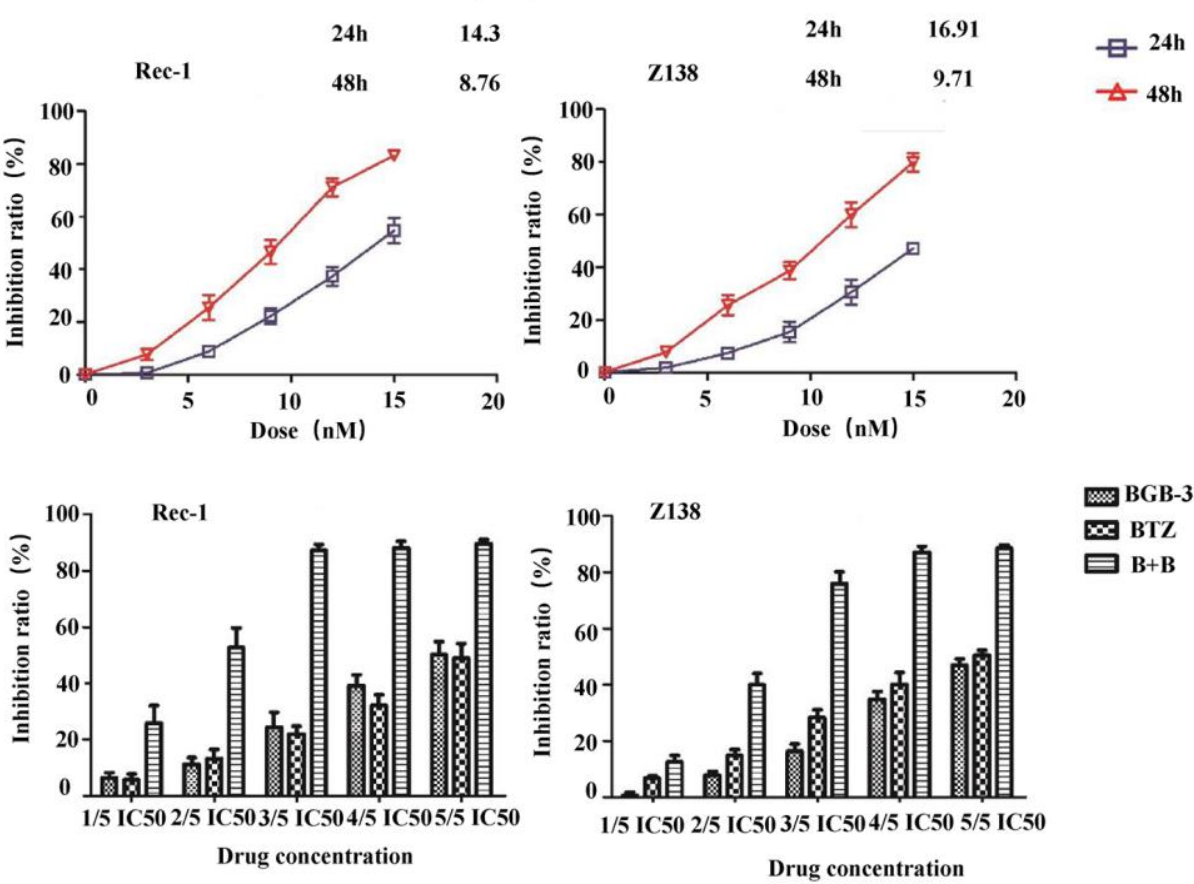

BGB-3111

$\cos B \mathrm{BTZ}$

曰 B+B

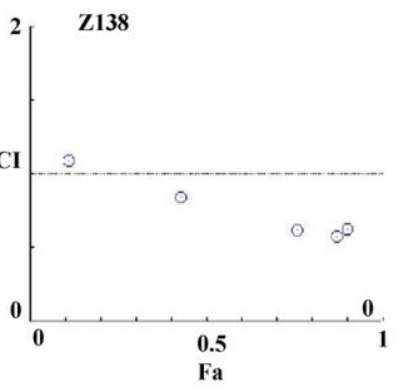

Figure 6. Low-dose BTZ enhances the inhibitory effect mediated by the low-dose BGB-3111 in the MCL cells. (A) Cell viability in the Jeko-1, Rec-1, and Z138 treated with varying doses of BTZ for 24 or 48 h. (B) Cell viability in the Jeko-1, Rec-1, and Z138 treated with single or combination of low-dose BGB-3111 and BTZ for 48 h. (C) The combination index of cell proliferation in the Jeko-1, Rec-1, and Z138 treated with low-dose BGB-3111 combined with low-dose BTZ. Results are the mean \pm SD of three independent experiments. 
BTZ enhanced cell apoptosis and cell-cycle arrest induced by BGB-3111 in the MCL cells

According to the above results, the inhibitory effect of $20 \%$ of the IC50 for both drugs is less limiting; $40 \%$ of the IC50 for BGB-3111 combined with $40 \%$ of the IC50 for BTZ could almost inhibit half of the cell proliferation, and we would like to use a low concentration to achieve a good inhibitory effect on the tumor cell growth. Therefore, we further selected the low dose of BGB-3111 (40\% of the IC50) and BTZ ( $40 \%$ of the IC50) to investigate the cell cycle arrest and cell apoptosis in the MCL cells expressing BTK. Figure $7 \mathrm{~A}$ and Supplementary Figure 3 show that the combination of low-dose BGB-3111 with low-dose BTZ resulted in a significant increase in cell apoptosis compared to a single agent in the Jeko-1, Rec-1, and Z138 cells after treatment for $48 \mathrm{~h}$. The apoptotic rates were $24.91 \% \pm 3.47 \%$ and $17.63 \% \pm 4.34 \%$ in Jeko- 1 cells for low-dose BGB-3111 and low-dose BTZ, respectively; however, it significantly increased to $63.19 \% \pm 6.65 \%$ for the combinatorial treatment of both low-dose drugs. The apoptotic rates were $23.64 \% \pm$ $7.86 \%$ and $22.25 \% \pm 3.39 \%$ in Rec- 1 cells for low-dose BGB-3111 and low-dose BTZ, respectively; however, it significantly increased to $64.89 \% \pm 5.47 \%$ for the combination treatment with both the low-dose drugs. The apoptotic rate was $12.56 \% \pm 2.02 \%$ and $19.80 \% \pm$ $3.42 \%$ in Z138 cells for low-dose BGB-3111 and lowdose BTZ, respectively; however, it significantly increased to $48.42 \% \pm 5.88 \%$ for the combination treatment with both low-dose drugs. At the same time, low-dose BTZ enhanced the cell cycle arrest induced by low-dose BGB-3111. The percentage of G1/G0 phase cells was $48.66 \% \pm 1.98 \%$ and $37.51 \% \pm 5.12 \%$ in the Jeko-1 cells for low-dose BGB-3111 and low-dose BTZ, respectively; however, it significantly increased to $77.48 \% \pm 3.25 \%$ for the combinatorial treatment of both

A

JeKo-1

Rec-1

Z138
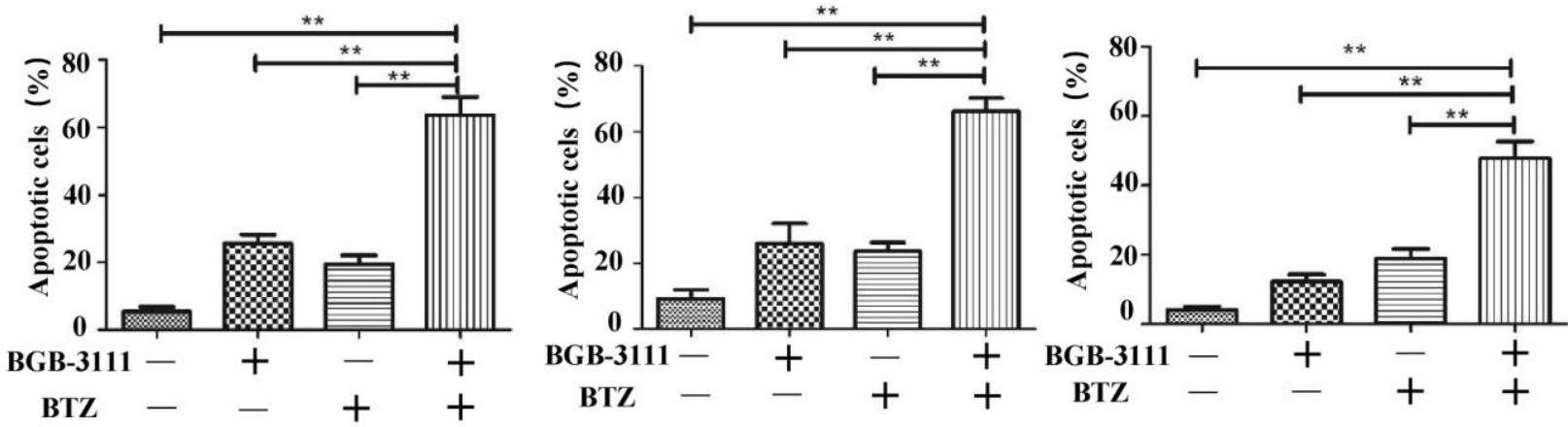

B
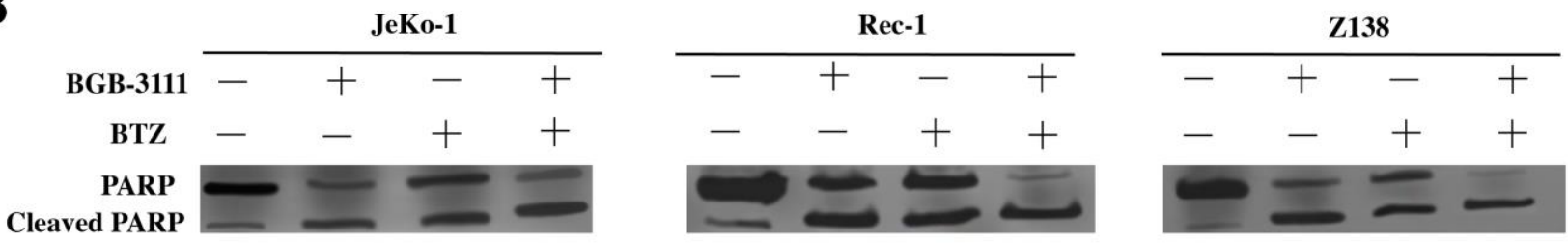

Cleaved caspase -9
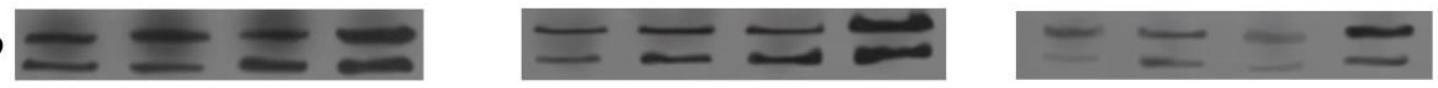

BCl-2
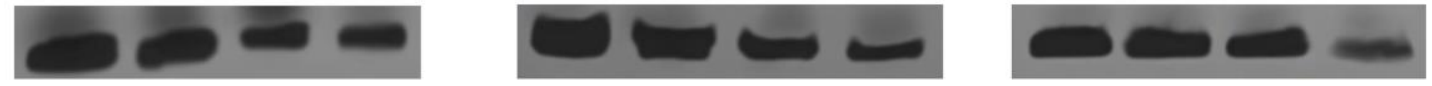

$\beta$-actin
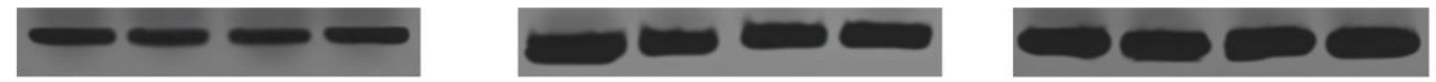

Figure 7. Low-dose BTZ enhances the cell apoptotic effect induced by low-dose BGB-3111 in the MCL cells. (A) Cell apoptotic distribution of the Jeko-1, Rec-1, and Z138 cells after being treated with low-dose BGB-3111, low-dose BTZ, and their combination for $48 \mathrm{~h}$. (B) The cell apoptotic rate was detected by flow cytometry. ${ }^{* *} p<0.01$. The expression levels of the apoptosis-related proteins in Jeko-1, Rec-1, and Z138 cells after treating with low-dose BGB-3111, low-dose BTZ, and their combination for $48 \mathrm{~h}$. 
the low-dose drugs. The percentage of G1/G0 phase cells was $60.10 \% \pm 5.12 \%$ and $40.69 \% \pm 3.28 \%$ in the Rec-1 cells for low-dose BGB-3111 and low-dose BTZ, respectively; however, it significantly increased to $80.74 \% \pm 2.22 \%$ for the combinatorial treatment of both the low-dose drugs. The percentage of G1/G0 phase cells was $46.92 \% \pm 1.21 \%$ and $30.75 \% \pm 3.01 \%$ in Z138 cells for low-dose BGB-3111 and low-dose BTZ, respectively; however, it significantly increased to $75.22 \% \pm 2.67 \%$ for the combinatorial treatment of both the low-dose drugs (Supplementary Figure 4). These results suggest that low-dose BTZ enhanced the cell apoptosis and cell-cycle arrest induced by low-dose BGB-3111 in the MCL cells.

\section{BTZ enhanced the anti-cancer effect of BGB-3111} by regulating the apoptosis-related proteins

To understand the underlying mechanism of the anticancer effect, the expression levels of the apoptosisrelated proteins, including PARP, caspase- 9 , and Bcl-2, were detected in the Jeko-1, Rec-1, and Z138 cells after treatment with low-dose BGB-3111 (40\% of the IC50) and BTZ (40\% of the IC50). Figure 7B shows that the combination of low-dose BGB-3111 with low-dose
BTZ enhanced the pro-apoptotic effect compared to a single agent treatment, increased cleaved PARP and caspase-9 expression, and inhibited Bcl-2 expression. These data indicate that the expression of PARP, cleaved caspase-9 and $\mathrm{Bcl}-2$ were significantly regulated in combination treatment, suggesting that these apoptosis-related proteins were involved in the anti-cancer process.

BTZ enhanced the anti-cancer effect of BGB-3111 by synergistically suppressing the NF- $\kappa B$ pathway

The NF- $\kappa B$ signaling pathway is downregulated by BTK as well as BTZ. Next, we investigated whether the expression of key proteins involved in NF- $\mathrm{KB}$ signaling was regulated in the Jeko-1, Rec-1, and Z138 cells after treatment with low-dose BGB-3111 (40\% of the IC50) and BTZ (40\% of the IC50). The results showed that the expression of the p-BTK protein was downregulated in these cells after treatment with low-dose BGB-3111, but not BTZ. The expression of $\mathrm{p}-\mathrm{I} \kappa \mathrm{B} \alpha$ and $\mathrm{p}-\mathrm{P} 65$ proteins were decreased in these cells after treatment with lowdose BGB-3111 or low-dose BTZ, but the combination strongly suppressed these protein expressions compared to the single-agent (Figure 8).

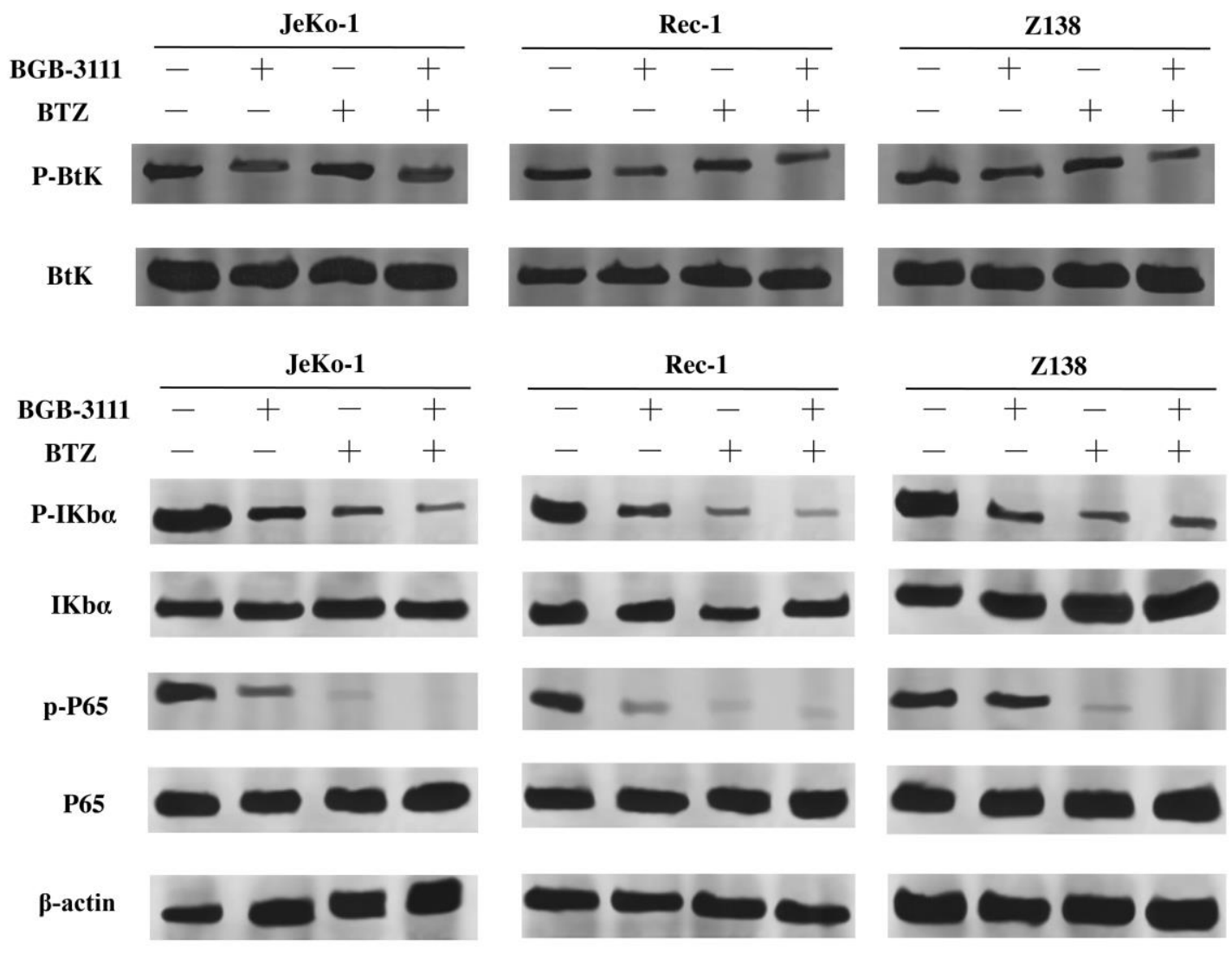

Figure 8. Expression levels of BTK, ІкB $\alpha$, P65 and their phosphorylation proteins in the Jeko-1, Rec-1, and Z138 cells after treating with low-dose BGB-3111, low-dose BTZ, and their combination for $48 \mathrm{~h}$. 


\section{DISCUSSION}

MCL is a relatively rare subtype of B-cell lymphoma with a poor prognosis. Ibrutinib, a first-generation BTK inhibitor, has shown promising efficacy in CLL/SLL, MCL, and WM [48-50]. However, it poses adverse effects usually appearing as off-target effects on the other kinases, including Tec family proteins. A novel and nextgeneration BTK inhibitor, BGB-3111, has been shown to be well-tolerated and highly active in CLL/SLL and WM in preclinical studies $[32,35]$. Herein, we found that BGB-3111 strongly inhibited cell proliferation, induced cell cycle arrest in the G1/G0-phase, and promoted cell apoptosis in the MCL cells expressing BTK, and showed a restricted off-target activity on ITK protein compared to ibrutinib. In combination with BTZ, low-dose BGB-3111 synergistically enhanced the anti-cancer effect by increasing cell-cycle arrest, regulating apoptosis-related proteins, and inhibiting the NF- $\mathrm{KB}$ pathway.

BTK is a key kinase in the BCR signaling pathway and shows persistent activation in MCL [51]. In this study, we found that $59.4 \%$ of MCL patients expressed the BTK protein, which is consistent with a previous report [52]. This suggests that targeting BTK is a promising treatment strategy for patients with MCL $[53,54]$. Cell proliferation is closely related to the cell cycle and apoptosis, and their dysregulations are the main characteristics of MCL [55]. Our results revealed that BGB-3111 decreased cell proliferation, induced cell apoptosis, and arrested the cell cycle in the G1/G0phase in MCL-expressing BTK.

BGB-3111 and ibrutinib have the same antineoplastic mechanism that binds to the Cys-481 residue in BTK. BTK belongs to a member of the Tec family of tyrosine kinases but is specifically expressed in the B-cells. Other Tec family members, such as ITKs, are expressed in the T-cells. Phosphorylation of ITK can activate its downstream signaling pathways [56] and lead to some toxicities, such as AF [57]. Our results showed that BGB-3111 had a restricted off-target activity on ITK in T-cells compared to ibrutinib, suggesting that BGB-3111 may have better safety. Moreover, we found that the combination of low-dose BGB-3111 with low-dose BTZ significantly enhanced the anti-cancer effects by increasing the expression of cleaved PARP and caspase9 and inhibiting Bcl-2 expression and further affecting the NF- $\kappa B$ pathway. The NF- $\kappa B$ signaling is constitutively activated in the MCL cells, which involves tumorigenesis by promoting cellular survival signals [58]. In this study, low-dose BGB-3111 treatment decreased the expression of BTK phosphorylation, whereas BTZ treatment did not change BTK phosphorylation. However, both low-dose BGB-3111 and low-dose BTZ alone decreased the phosphorylation of IкB- $\alpha$ and P65 phosphorylation in the MCL cells. The combination of low-dose BGB-3111 with low-dose BTZ enhanced the anti-cancer effects through the NF- $\kappa B$ pathway. However, this was only a preliminary finding of the synergistic effect of BGB-3111 and BTZ, and further studies are needed to explore the detailed mechanism and the effect on the resistance of the MCL cell lines. Our data provide a potential therapeutic strategy for the combinatorial treatment of the low dose of both the drugs to gain strong anti-cancer effects and better safety for the patients with MCL.

In conclusion, BTK is highly expressed in the tissues of MCL patients. BGB-3111 is a potentially novel and effective BTK inhibitor for the treatment of MCL with a higher BTK specificity compared to ibrutinib. Lowdose BTZ might further enhance the anti-cancer effect of low-dose BGB-3111 in MCL expressing BTK, suggesting that the combination of low-dose BGB-3111 and low-dose BTZ is a potential and effective therapeutic strategy for MCL patients.

\section{MATERIALS AND METHODS}

\section{Patient samples}

We obtained 32 formalin-fixed paraffin-embedded (FFPE) tissues from the MCL patients at the Tianjin Medical University Cancer Institute and Hospital (TMUCIH). Each specimen was reviewed by two experienced hematopathologists for diagnostic confirmation. In addition, 10 specimens of the normal lymph gland tissue obtained from patients with reactive hyperplasia of the lymph nodes in TMUCIH were used as controls. The study was approved by the Clinical Research Ethics Board of TMUCIH, and written informed consent was provided by all the participating patients. This study was conducted in accordance with the 1964 Declaration of Helsinki.

\section{Immunohistochemistry and scoring of BTK}

The immunohistochemical staining was performed to quantify the BTK proteins. Briefly, the FFPE slides were dewaxed, rehydrated, and antigen-retrieved (Tris-EDTA buffer, $\mathrm{pH}$ 9.0). Next, they were blocked with $10 \%$ goat serum for $30 \mathrm{~min}$ at $37^{\circ} \mathrm{C}$ before incubating the sample in the BTK primary antibody (1:200, Cell Signaling Technology Inc., MA) overnight at $4^{\circ} \mathrm{C}$. They were then incubated with a secondary antibody for $60 \mathrm{~min}$ at $37^{\circ} \mathrm{C}$. The chromagen 3, 3'-diaminobenzidine (DAKO, Carpenteria, CA) was applied for $5 \mathrm{~min}$, and the slides were counterstained with hematoxylin and then stored at $4^{\circ} \mathrm{C}$ before imaging under a microscope. The positive percentage and staining intensity of the tumor cells were evaluated for each slide. Briefly, the positive percentage 
was classified into $0-3$ scores $(0,0-5 \%$ positivity; 1 , 5-25\% positivity; $2,25-50 \%$ positivity; and $3, \geq 50 \%$ positivity), and the staining intensity was also categorized into 0-3 scores (0, absent; 1 , weak; 2 , moderate; and 3, strong). The expression of BTK was evaluated by two experienced hematopathologists who were blinded to the sample identities. The semiquantitative $\mathrm{H}$-scores were calculated by multiplying the percentage score by the intensity score. The high BTK expression was defined as $\mathrm{H}$-scores $\geq 6$, and the low BTK expression was defined as H-scores $<6$.

\section{Cell lines and reagents}

Human MCL cell lines including Jeko-1, Rec-1, Z138, Grant 519, and Mino, and human T-cell line, Jurkat were provided by Dr. Kai Fu (University of Nebraska Medical Center, NE, USA). These cells were maintained in the RPMI 1640 media supplemented with $10 \%$ fetal bovine serum (FBS, Thermo Fisher Scientific, MA, USA) and $1 \%$ penicillin/streptomycin was added, and cultured at $37^{\circ} \mathrm{C}$ with $5 \% \mathrm{CO}_{2}$. The BGB-3111 was supplied as a gift by BeiGene Ltd. (Beijing, China). BTZ and ibrutinib were purchased from Selleck Chemicals (Houston, TX, USA).

\section{Cell viability assay}

The cells were treated with various doses of BGB-3111 or/and BTZ, and then cell viability was determined after $48 \mathrm{~h}$ or $72 \mathrm{~h}$ incubation using a CellTiter 96 Aqueous One Solution Cell Proliferation Assay (Promega, Madison, WI, USA, Cat. \#G3580) according to the manufacturer's protocol. The IC50 (50\% inhibitory concentration) values were calculated using GraphPad Prism software (version 5.0). The data were confirmed by performing at least three independent experiments.

\section{Cell cycle assay}

The cells were treated with BGB-3111 or/and BTZ for $48 \mathrm{~h}$, washed, resuspended in cold PBS, and fixed by dropwise addition of ice-cold absolute ethanol to a final concentration of $70 \%$. The fixed cells were stored at $4^{\circ} \mathrm{C}$ overnight, pelleted, and incubated with RNase A (Solarbio, China, final concentration of $0.2 \mathrm{mg} / \mathrm{ml}$ ), and propidium iodide (Sigma-Aldrich, final concentration was $50 \mu \mathrm{g} / \mathrm{ml}$ ) for $30 \mathrm{~min}$ at $37^{\circ} \mathrm{C}$ in the dark. The cell cycle was analyzed on a FACSCelesta flow cytometer (BD Bioscience, CA, USA) using ModFit LT 4.1 software.

\section{Cell apoptosis assay}

The cells were treated with BGB-3111 and/or BTZ for $48 \mathrm{~h}$ and then rinsed with cold PBS. After centrifugation at $300 \times g$ for $5 \mathrm{~min}$, cells were resuspended in $100 \mu \mathrm{l}$ binding buffer (BD Biosciences, CA, USA), and then $5 \mu \mathrm{l}$ of Annexin V-FITC and $5 \mu \mathrm{l}$ of PI were added following the apoptosis detection kit manufacturer's protocol (BD Biosciences, San Diego, CA). The samples were analyzed by FACSCelesta flow cytometry after incubation for $15 \mathrm{~min}$ in the dark at room temperature (RT). The results were analyzed using FlowJo V10 software.

\section{Synergy evaluation of the anti-cancer effect in combinatorial treatment}

The cells were treated with BGB-3111 and/or BTZ at concentrations that were $20 \%, 40 \%, 60 \%, 80 \%$, and $100 \%$ of the IC50 for $48 \mathrm{~h}$. Cell viability was determined as described above. The effects of the combined treatment were calculated by the CompuSyn software using the Chou-Talalay combination index (CI) and isobologram methods according to the medianeffect principle. The combination effect was designated as synergism ( $\mathrm{CI}<1.0)$, addition $(\mathrm{CI}=1.0)$, or antagonism $(\mathrm{CI}>1.0)$.

\section{Western immunoblotting}

The treated cells were harvested in the RIPA lysis buffer containing $1 \mathrm{mM}$ PMSF and phosphatase inhibitor cocktail. The whole-cell lysates were centrifuged at $12,000 \times g$ at $4^{\circ} \mathrm{C}$ for $10 \mathrm{~min}$, and the total protein was quantitated using the BCA method (Thermo Fisher Scientific, MA, USA). A $20-50 \mu \mathrm{g}$ of Total protein was separated by the $10 \%$ SDS-PAGE gel electrophoresis and subsequently transferred to the PVDF membranes (Roche, UK) at $260 \mathrm{~mA}$ for $2 \mathrm{~h}$. Then, the blot was blocked in $5 \%$ bovine serum albumin for $1 \mathrm{~h}$ at RT and incubated with the specific primary antibodies at $4^{\circ} \mathrm{C}$ overnight. After washing three times in Tris-buffered saline-Tween for $10 \mathrm{~min}$, the blots were probed with 1:2000 dilution of goat anti-rabbit IgG or anti-mouse IgG horseradish peroxidase-conjugated secondary antibodies (SigmaAldrich, MO, USA) for $1 \mathrm{~h}$ at RT. The signals were detected using the chemiluminescence reagent Immobilon (Merck Millipore, Darmstadt, Germany). The signal intensity was obtained using the Image Studio Lite software. Antibodies, including the rabbit anti-human BTK, rabbit anti-human phospho-BTK, mouse anti-human cleaved caspase-9, mouse antihuman PARP, rabbit anti-human $\mathrm{I} \kappa \mathrm{B} \alpha$, rabbit antihuman phospho-I $\mathrm{KB} \alpha$, mouse anti-human P65, and rabbit anti-human phospho-P65, were obtained from the Cell Signaling Technology Inc. (Beverly, MA, USA). The rabbit anti-human Bcl-2 antibody was purchased from ProteinTech Group, Inc. (Hubei, China). The mouse monoclonal anti- $\beta$-actin was 
supplied by Sigma-Aldrich and used as an endogenous protein for normalization.

\section{Statistical analysis}

All the assays were presented as mean \pm standard deviation (SD) and were examined for significant differences using the Student's $t$-test. The differences were analyzed by the one-way analysis of variance using the IBM SPSS Statistics 20 software. Statistical significance was set at $P<0.05$.

\section{AUTHOR CONTRIBUTIONS}

XW, YF, XL, TZ, WL, and XJ performed the research; $\mathrm{XW}, \mathrm{HZ}$, and LL designed the research study; XW, YF, $\mathrm{XL}, \mathrm{TZ}$, and WL analyzed the data; HZ, XL, LQ, ZQ, and SZ provided MCL samples; XR, QZ, BM contributed essential reagents and pathological evaluation. XW, YF, and XJ wrote the manuscript. XW and $\mathrm{HZ}$ revised the manuscript.

\section{ACKNOWLEDGMENTS}

The authors greatly appreciate BeiGene Ltd., for supplying the BGB-3111, and the National Human Genetic Resources Sharing Service Platform (2005DKA21300)/Cancer Biobank of Tianjin Medical University Cancer Institute and Hospital.

\section{CONFLICTS OF INTEREST}

The authors declare no conflicts of interest related to this study.

\section{FUNDING}

This study was supported by the Natural Science Foundation of Tianjin (19JCYBJC26500, 18JCZDJC45100), the National Natural Science Foundation of China (81770213, 81670184), the National Key New Drug Creation Special Programs (2017ZX09304-021, 2018ZX09201015), and the Clinical Oncology Research Fund of CSCO (YXD2019-162).

\section{Editorial Note}

\&This corresponding author has a verified history of publications using the personal email address for correspondence.

\section{REFERENCES}

1. O'Connor OA. Mantle cell lymphoma: identifying novel molecular targets in growth and survival pathways. Hematology Am Soc Hematol Educ Program. 2007; 2007:270-76.

https://doi.org/10.1182/asheducation-2007.1.270 PMID: 18024640

2. Yoon DH, Cao J, Chen TY, Izutsu K, Kim SJ, Kwong YL, Lin TY, Thye LS, Xu B, Yang DH, Kim WS. Treatment of mantle cell lymphoma in Asia: a consensus paper from the Asian Lymphoma Study Group. J Hematol Oncol. 2020; 13:21.

https://doi.org/10.1186/s13045-020-00855-9 PMID:32183871

3. Sant M, Allemani C, Tereanu C, De Angelis R, Capocaccia R, Visser O, Marcos-Gragera R, Maynadié $M$, Simonetti A, Lutz JM, Berrino F, and HAEMACARE Working Group. Incidence of hematologic malignancies in Europe by morphologic subtype: results of the HAEMACARE project. Blood. 2010; 116:3724-34. https://doi.org/10.1182/blood-2010-05-282632 PMID:20664057

4. Smith A, Howell D, Patmore R, Jack A, Roman E. Incidence of haematological malignancy by sub-type: a report from the Haematological Malignancy Research Network. Br J Cancer. 2011; 105:1684-92. https://doi.org/10.1038/bjc.2011.450 PMID:22045184

5. Fu S, Wang M, Lairson DR, Li R, Zhao B, Du XL. Trends and variations in mantle cell lymphoma incidence from 1995 to 2013: A comparative study between Texas and National SEER areas. Oncotarget. 2017; 8:112516-29.

https://doi.org/10.18632/oncotarget.22367 PMID:29348844

6. Shah BD, Martin P, Sotomayor EM. Mantle cell lymphoma: a clinically heterogeneous disease in need of tailored approaches. Cancer Control. 2012; 19:227-35.

https://doi.org/10.1177/107327481201900307 PMID:22710898

7. Maddocks K. Update on mantle cell Iymphoma. Blood. 2018; 132:1647-56. https://doi.org/10.1182/blood-2018-03-791392 PMID: 30154113

8. Navarro A, Clot G, Royo C, Jares P, Hadzidimitriou A, Agathangelidis A, Bikos V, Darzentas N, Papadaki T, Salaverria I, Pinyol M, Puig X, Palomero J, et al. Molecular subsets of mantle cell lymphoma defined by the IGHV mutational status and SOX11 expression have distinct biologic and clinical features. Cancer Res. 2012; 72:5307-16.

https://doi.org/10.1158/0008-5472.CAN-12-1615 PMID:22915760

9. Ondrejka SL, Lai R, Smith SD, Hsi ED. Indolent mantle cell leukemia: a clinicopathological variant 
characterized by isolated lymphocytosis, interstitial bone marrow involvement, kappa light chain restriction, and good prognosis. Haematologica. 2011; 96:1121-27.

https://doi.org/10.3324/haematol.2010.036277 PMID:21508124

10. Hu Z, Sun Y, Schlette EJ, Tang G, Li S, Xu J, Yin CC, Young KH, Patel KP, Miranda RN, Goswami M, Wang $\mathrm{M}$, Jorgensen $\mathrm{JL}$, et al. CD200 expression in mantle cell lymphoma identifies a unique subgroup of patients with frequent IGHV mutations, absence of SOX11 expression, and an indolent clinical course. Mod Pathol. 2018; 31:327-36.

https://doi.org/10.1038/modpathol.2017.135 PMID:28984300

11. Ye H, Desai A, Zeng D, Nomie K, Romaguera J, Ahmed M, Wang ML. Smoldering mantle cell lymphoma. J Exp Clin Cancer Res. 2017; 36:185.

https://doi.org/10.1186/s13046-017-0652-8 PMID:29246179

12. Swerdlow SH, Campo E, Pileri SA, Harris NL, Stein H, Siebert R, Advani R, Ghielmini M, Salles GA, Zelenetz $A D$, Jaffe ES. The 2016 revision of the World Health Organization classification of lymphoid neoplasms. Blood. 2016; 127:2375-90.

https://doi.org/10.1182/blood-2016-01-643569 PMID:26980727

13. Pérez-Galán $P$, Dreyling $M$, Wiestner $A$. Mantle cell lymphoma: biology, pathogenesis, and the molecular basis of treatment in the genomic era. Blood. 2011; 117:26-38.

https://doi.org/10.1182/blood-2010-04-189977 PMID:20940415

14. Jares P, Colomer D, Campo E. Genetic and molecular pathogenesis of mantle cell lymphoma: perspectives for new targeted therapeutics. Nat Rev Cancer. 2007; 7:750-62.

https://doi.org/10.1038/nrc2230

PMID: 17891190

15. Kuo PY, Jatiani SS, Rahman AH, Edwards D, Jiang Z, Ahr K, Perumal D, Leshchenko VV, Brody J, Shaknovich R, Ye BH, Parekh S. SOX11 augments BCR signaling to drive MCL-like tumor development. Blood. 2018; 131:2247-55.

https://doi.org/10.1182/blood-2018-02-832535

PMID:29615403

16. Palomero J, Vegliante $M C$, Eguileor $A$, Rodríguez $M L$, Balsas P, Martínez D, Campo E, Amador V. SOX11 defines two different subtypes of mantle cell lymphoma through transcriptional regulation of BCL6. Leukemia. 2016; 30:1596-99.

https://doi.org/10.1038/leu.2015.355

PMID:26710884
17. Eskelund CW, Dahl C, Hansen JW, Westman M, Kolstad A, Pedersen LB, Montano-Almendras CP, Husby $S$, Freiburghaus C, Ek S, Pedersen A, Niemann C, Räty R, et al. TP53 mutations identify younger mantle cell lymphoma patients who do not benefit from intensive chemoimmunotherapy. Blood. 2017; 130:1903-10.

https://doi.org/10.1182/blood-2017-04-779736 PMID:28819011

18. Jares P, Colomer D, Campo E. Molecular pathogenesis of mantle cell lymphoma. J Clin Invest. 2012; 122:3416-23.

https://doi.org/10.1172/JCl61272

PMID:23023712

19. Advani RH, Buggy JJ, Sharman JP, Smith SM, Boyd TE, Grant B, Kolibaba KS, Furman RR, Rodriguez $S$, Chang BY, Sukbuntherng J, Izumi R, Hamdy A, et al. Bruton tyrosine kinase inhibitor ibrutinib (PCl-32765) has significant activity in patients with relapsed/refractory B-cell malignancies. J Clin Oncol. 2013; 31:88-94. https://doi.org/10.1200/JCO.2012.42.7906 PMID:23045577

20. Satterthwaite $A B$, Witte $O N$. The role of Bruton's tyrosine kinase in B-cell development and function: a genetic perspective. Immunol Rev. 2000; 175:120-27. PMID: 10933597

21. Ponader S, Burger JA. Bruton's tyrosine kinase: from $\mathrm{X}$-linked agammaglobulinemia toward targeted therapy for B-cell malignancies. J Clin Oncol. 2014; 32:1830-39.

https://doi.org/10.1200/JCO.2013.53.1046 PMID:24778403

22. McMullen JR, Boey EJ, Ooi JY, Seymour JF, Keating MJ, Tam CS. Ibrutinib increases the risk of atrial fibrillation, potentially through inhibition of cardiac PI3K-Akt signaling. Blood. 2014; 124:3829-30. https://doi.org/10.1182/blood-2014-10-604272 PMID:25498454

23. Tuomi JM, Xenocostas A, Jones DL. Increased Susceptibility for Atrial and Ventricular Cardiac Arrhythmias in Mice Treated With a Single High Dose of Ibrutinib. Can J Cardiol. 2018; 34:337-41. https://doi.org/10.1016/j.cjca.2017.12.001 PMID:29475534

24. Cheng C, Woronow D, Nayernama A, Wroblewski T, Jones SC. Ibrutinib-associated ventricular arrhythmia in the FDA Adverse Event Reporting System. Leuk Lymphoma. 2018; 59:3016-17.

https://doi.org/10.1080/10428194.2018.1457149 PMID:29792382

25. Levade M, David E, Garcia C, Laurent PA, Cadot S, Michallet AS, Bordet JC, Tam C, Sié P, Ysebaert L, Payrastre B. Ibrutinib treatment affects collagen and 
von Willebrand factor-dependent platelet functions. Blood. 2014; 124:3991-95.

https://doi.org/10.1182/blood-2014-06-583294 PMID:25305202

26. Byrd JC, Furman RR, Coutre SE, Burger JA, Blum KA, Coleman M, Wierda WG, Jones JA, Zhao W, Heerema NA, Johnson AJ, Shaw Y, Bilotti E, et al. Three-year follow-up of treatment-naïve and previously treated patients with CLL and SLL receiving single-agent ibrutinib. Blood. 2015; 125:2497-506.

https://doi.org/10.1182/blood-2014-10-606038 PMID:25700432

27. Burger JA, Tedeschi A, Barr PM, Robak T, Owen C, Ghia P, Bairey O, Hillmen P, Bartlett NL, Li J, Simpson D, Grosicki S, Devereux S, et al, and RESONATE-2 Investigators. Ibrutinib as Initial Therapy for Patients with Chronic Lymphocytic Leukemia. N Engl J Med. 2015; 373:2425-37.

https://doi.org/10.1056/NEJMoa1509388

PMID:26639149

28. Hershkovitz-Rokah O, Pulver D, Lenz G, Shpilberg O. Ibrutinib resistance in mantle cell lymphoma: clinical, molecular and treatment aspects. $\mathrm{Br} J$ Haematol. 2018; 181:306-19.

https://doi.org/10.1111/bjh.15108

PMID:29359797

29. Lee J, Zhang LL, Wu W, Guo H, Li Y, Sukhanova M, Venkataraman $G$, Huang S, Zhang $H$, Alikhan $M$, Lu P, Guo A, Galanina N, et al. Activation of MYC, a bona fide client of HSP90, contributes to intrinsic ibrutinib resistance in mantle cell lymphoma. Blood Adv. 2018; 2:2039-2051.

https://doi.org/10.1182/bloodadvances.2018016048 PMID:30115641

30. Jain $P$, Kanagal-Shamanna $R$, Zhang $S$, Ahmed $M$, Ghorab A, Zhang L, Ok CY, Li S, Hagemeister F, Zeng D, Gong T, Chen W, Badillo $\mathrm{M}$, et al. Long-term outcomes and mutation profiling of patients with mantle cell lymphoma (MCL) who discontinued ibrutinib. Br J Haematol. 2018; 183:578-87.

https://doi.org/10.1111/bjh.15567

PMID:30175400

31. Martin P, Maddocks K, Leonard JP, Ruan J, Goy A, Wagner-Johnston N, Rule S, Advani R, Iberri D, Phillips T, Spurgeon S, Kozin E, Noto K, et al. Postibrutinib outcomes in patients with mantle cell lymphoma. Blood. 2016; 127:1559-63.

https://doi.org/10.1182/blood-2015-10-673145 PMID:26764355

32. Tam C, Grigg AP, Opat S, Ku M, Gilbertson M, Anderson MA, Seymour JF, Ritchie DS, Dicorleto C, Dimovski B, Hedrick E, Yang J, Wang L, et al. The BTK Inhibitor, Bgb-3111, Is Safe, Tolerable, and Highly
Active in Patients with Relapsed/Refractory B-Cell Malignancies: Initial Report of a Phase 1 First-inHuman Trial. Blood. 2015; 126:832. https://doi.org/10.1182/blood.V126.23.832.832

33. Li N, Sun Z, Liu Y, Guo M, Zhang Y, Zhou D, Zhang B, Su D, Zhang S, Han J, Gao Y, Guo Y, Wang Z, et al. BGB3111 is a novel and highly selective Bruton's tyrosine kinase (BTK) inhibitor. Cancer Research. 2015; 75:2597. https://doi.org/10.1158/1538-7445.AM2015-2597

34. Tam CS, Opat S, Cull G, Trotman J, Gottlieb D, Simpson D, Marlton P, Anderson MA, Ku M, Ritchie D, Ratnasingam S, Augustson B, Kirschbaum M, et al. Twice Daily Dosing with the Highly Specific BTK Inhibitor, Bgb-3111, Achieves Complete and Continuous BTK Occupancy in Lymph Nodes, and Is Associated with Durable Responses in Patients (pts) with Chronic Lymphocytic Leukemia (CLL)/Small Lymphocytic Lymphoma (SLL). Blood. 2016; 128:642. https://doi.org/10.1182/blood.V128.22.642.642

35. Tam CS, Trotman J, Opat S, Marlton P, Cull G, Simpson D, Ku M, Ritchie D, Verner E, Ratnasingam S, Anderson MA, Wood P, Kirschbaum M, et al. High Major Response Rate, Including Very Good Partial Responses (VGPR), in Patients (pts) with Waldenstrom Macroglobulinemia (WM) Treated with the Highly Specific BTK Inhibitor Bgb-3111: Expansion Phase Results from an Ongoing Phase I Study. Blood. 2016; 128:1216.

https://doi.org/10.1182/blood.V128.22.1216.1216

36. Tam CS, Trotman J, Opat S, Burger JA, Cull G, Gottlieb D, Harrup R, Johnston PB, Marlton P, Munoz J, Seymour JF, Simpson D, Tedeschi A, et al. Phase 1 study of the selective BTK inhibitor zanubrutinib in Bcell malignancies and safety and efficacy evaluation in CLL. Blood. 2019; 134:851-59.

https://doi.org/10.1182/blood.2019001160 PMID:31340982

37. Song $Y$, Zhou $K$, Zou D, Zhou J, Hu J, Yang H, Zhang H, Ji J, Xu W, Jin J, Lv F, Feng R, Gao S, et al. Treatment of Patients with Relapsed or Refractory Mantle-Cell Lymphoma with Zanubrutinib, a Selective Inhibitor of Bruton's Tyrosine Kinase. Clin Cancer Res. 2020; 26:4216-24.

https://doi.org/10.1158/1078-0432.CCR-19-3703 PMID:32461234

38. Trotman J, Opat S, Gottlieb D, Simpson D, Marlton P, Cull G, Munoz J, Tedeschi A, Roberts AW, Seymour JF, Atwal SK, Yu Y, Novotny W, et al. Zanubrutinib for the treatment of patients with Waldenström macroglobulinemia: 3 years of follow-up. Blood. 2020; 136:2027-37.

https://doi.org/10.1182/blood.2020006449

PMID:32698195 
39. Hoffmann A, Natoli G, Ghosh G. Transcriptional regulation via the NF-kappaB signaling module. Oncogene. 2006; 25:6706-16.

https://doi.org/10.1038/sj.onc.1209933

PMID: $\underline{17072323}$

40. Goy A, Bernstein SH, Kahl BS, Djulbegovic B, Robertson MJ, de Vos S, Epner E, Krishnan A, Leonard JP, Lonial S, Nasta S, O'Connor OA, Shi H, et al. Bortezomib in patients with relapsed or refractory mantle cell lymphoma: updated time-to-event analyses of the multicenter phase 2 PINNACLE study. Ann Oncol. 2009; 20:520-25. https://doi.org/10.1093/annonc/mdn656 PMID: 19074748

41. Fisher RI, Bernstein $\mathrm{SH}$, Kahl BS, Djulbegovic B, Robertson MJ, de Vos S, Epner E, Krishnan A, Leonard JP, Lonial S, Stadtmauer EA, O'Connor OA, Shi H, et al. Multicenter phase II study of bortezomib in patients with relapsed or refractory mantle cell lymphoma. J Clin Oncol. 2006; 24:4867-74. https://doi.org/10.1200/JCO.2006.07.9665 PMID:17001068

42. O'Connor OA, Moskowitz C, Portlock C, Hamlin P, Straus D, Dumitrescu O, Sarasohn D, Gonen M, Butos J, Neylon E, Hamelers R, Mac-Gregor Cortelli B, Blumel S, et al. Patients with chemotherapy-refractory mantle cell lymphoma experience high response rates and identical progression-free survivals compared with patients with relapsed disease following treatment with single agent bortezomib: results of a multicentre Phase 2 clinical trial. Br J Haematol. 2009; 145:34-39. https://doi.org/10.1111/j.1365-2141.2008.07466.x PMID:19220284

43. Robak T, Huang $H$, Jin J, Zhu J, Liu T, Samoilova O, Pylypenko H, Verhoef G, Siritanaratkul N, Osmanov E, Alexeeva J, Pereira J, Drach J, et al, and LYM-3002 Investigators. Bortezomib-based therapy for newly diagnosed mantle-cell lymphoma. N Engl J Med. 2015; 372:944-53.

https://doi.org/10.1056/NEJMoa1412096 PMID:25738670

44. Romaguera JE, Wang $M$, Feng $L$, Fayad LE, Hagemeister $F$, McLaughlin $P$, Rodriguez MA, Fanale M, Orlowski R, Kwak LW, Neelapu S, Oki Y, Pro B, et al. Phase 2 trial of bortezomib in combination with rituximab plus hyperfractionated cyclophosphamide, vincristine, doxorubicin, and dexamethasone alternating with bortezomib, rituximab, methotrexate, and cytarabine for untreated mantle cell lymphoma. Cancer. 2018; 124:2561-69.

https://doi.org/10.1002/cncr.31361 PMID:29723393

45. Robak T, Jin J, Pylypenko H, Verhoef G, Siritanaratkul N, Drach J, Raderer M, Mayer J, Pereira J, Tumyan G,
Okamoto R, Nakahara S, Hu P, et al, and LYM-3002 investigators. Frontline bortezomib, rituximab, cyclophosphamide, doxorubicin, and prednisone (VRCAP) versus rituximab, cyclophosphamide, doxorubicin, vincristine, and prednisone (R-CHOP) in transplantation-ineligible patients with newly diagnosed mantle cell lymphoma: final overall survival results of a randomised, open-label, phase 3 study. Lancet Oncol. 2018; 19:1449-58.

https://doi.org/10.1016/S1470-2045(18)30685-5 PMID: 30348538

46. Gressin R, Daguindau N, Tempescul A, Moreau A, Carras S, Tchernonog E, Schmitt A, Houot R, Dartigeas C, Pignon JM, Corm S, Banos A, Mounier C, et al, and Lymphoma Study Association. A phase 2 study of rituximab, bendamustine, bortezomib and dexamethasone for first-line treatment of older patients with mantle cell lymphoma. Haematologica. 2019; 104:138-46.

https://doi.org/10.3324/haematol.2018.191429 PMID: 30171024

47. Hideshima $T$, Richardson $P$, Chauhan D, Palombella VJ, Elliott PJ, Adams J, Anderson KC. The proteasome inhibitor PS-341 inhibits growth, induces apoptosis, and overcomes drug resistance in human multiple myeloma cells. Cancer Res. 2001; 61:3071-76.

PMID: $\underline{11306489}$

48. Jeon YW, Yoon S, Min GJ, Park SS, Park S, Yoon JH, Lee SE, Cho BS, Eom KS, Kim YJ, Kim HJ, Lee S, Min CK, et al. Clinical outcomes for ibrutinib in relapsed or refractory mantle cell lymphoma in real-world experience. Cancer Med. 2019; 8:6860-70.

https://doi.org/10.1002/cam4.2565

PMID: $\underline{31560165}$

49. Burger JA, Barr PM, Robak T, Owen C, Ghia P, Tedeschi A, Bairey O, Hillmen P, Coutre SE, Devereux S, Grosicki $\mathrm{S}, \mathrm{McCarthy} H$, Simpson D, et al. Long-term efficacy and safety of first-line ibrutinib treatment for patients with CLL/SLL: 5 years of follow-up from the phase 3 RESONATE-2 study. Leukemia. 2020; 34:787-98. https://doi.org/10.1038/s41375-019-0602-x PMID: $\underline{31628428}$

50. Tam CS, Opat S, D'Sa S, Jurczak W, Lee HP, Cull G, Owen RG, Marlton P, Wahlin BE, Sanz RG, McCarthy $H$, Mulligan S, Tedeschi A, et al. A randomized phase 3 trial of zanubrutinib vs ibrutinib in symptomatic Waldenström macroglobulinemia: the ASPEN study. Blood. 2020; 136:2038-50.

https://doi.org/10.1182/blood.2020006844 PMID: $\underline{32731259}$

51. Bernard S, Danglade D, Gardano L, Laguillier C, Lazarian G, Roger C, Thieblemont C, Marzec J, Gribben J, Cymbalista F, Varin-Blank N, Ledoux D, Baran-Marszak 
F. Inhibitors of BCR signalling interrupt the survival signal mediated by the micro-environment in mantle cell lymphoma. Int J Cancer. 2015; 136:2761-74.

https://doi.org/10.1002/ijc.29326

PMID:25388373

52. Cinar M, Hamedani F, Mo Z, Cinar B, Amin HM, Alkan S. Bruton tyrosine kinase is commonly overexpressed in mantle cell lymphoma and its attenuation by Ibrutinib induces apoptosis. Leuk Res. 2013; 37:1271-77.

https://doi.org/10.1016/i.leukres.2013.07.028 PMID:23962569

53. Aalipour A, Advani RH. Bruton tyrosine kinase inhibitors: a promising novel targeted treatment for $\mathrm{B}$ cell lymphomas. Br J Haematol. 2013; 163:436-43.

https://doi.org/10.1111/bjh.12573

PMID:24111579

54. Byrd JC, Harrington B, O'Brien S, Jones JA, Schuh A, Devereux S, Chaves J, Wierda WG, Awan FT, Brown JR, Hillmen P, Stephens DM, Ghia P, et al. Acalabrutinib (ACP-196) in Relapsed Chronic Lymphocytic Leukemia. N Engl J Med. 2016; 374:323-32. https://doi.org/10.1056/NEJMoa1509981 PMID:26641137

55. Abrams JM, White MA. Coordination of cell death and the cell cycle: linking proliferation to death through private and communal couplers. Curr Opin Cell Biol. 2004; 16:634-38. https://doi.org/10.1016/j.ceb.2004.09.010 PMID:15530774
56. Dubovsky JA, Chappell DL, Harrington BK, Agrawal K, Andritsos LA, Flynn JM, Jones JA, Paulaitis ME, Bolon B, Johnson AJ, Byrd JC, Muthusamy N. Lymphocyte cytosolic protein 1 is a chronic lymphocytic leukemia membrane-associated antigen critical to niche homing. Blood. 2013; 122:3308-16.

https://doi.org/10.1182/blood-2013-05-504597

PMID:24009233

57. Alberelli MA, Innocenti I, Sica S, Laurenti L, De Candia E. PO-54 - Clinical and laboratory characterization of platelet dysfunction caused by ibrutinib treatment in patients with chronic lymphocytic leukemia. Thromb Res. 2016 (Suppl 1); 140:S196.

https://doi.org/10.1016/S0049-3848(16)30187-6 PMID:27161742

58. Bharti AC, Aggarwal BB. Nuclear factor-kappa B and cancer: its role in prevention and therapy. Biochem Pharmacol. 2002; 64:883-88.

https://doi.org/10.1016/s0006-2952(02)01154-1 PMID:12213582 


\section{SUPPLEMENTARY MATERIALS}

Supplementary Figures
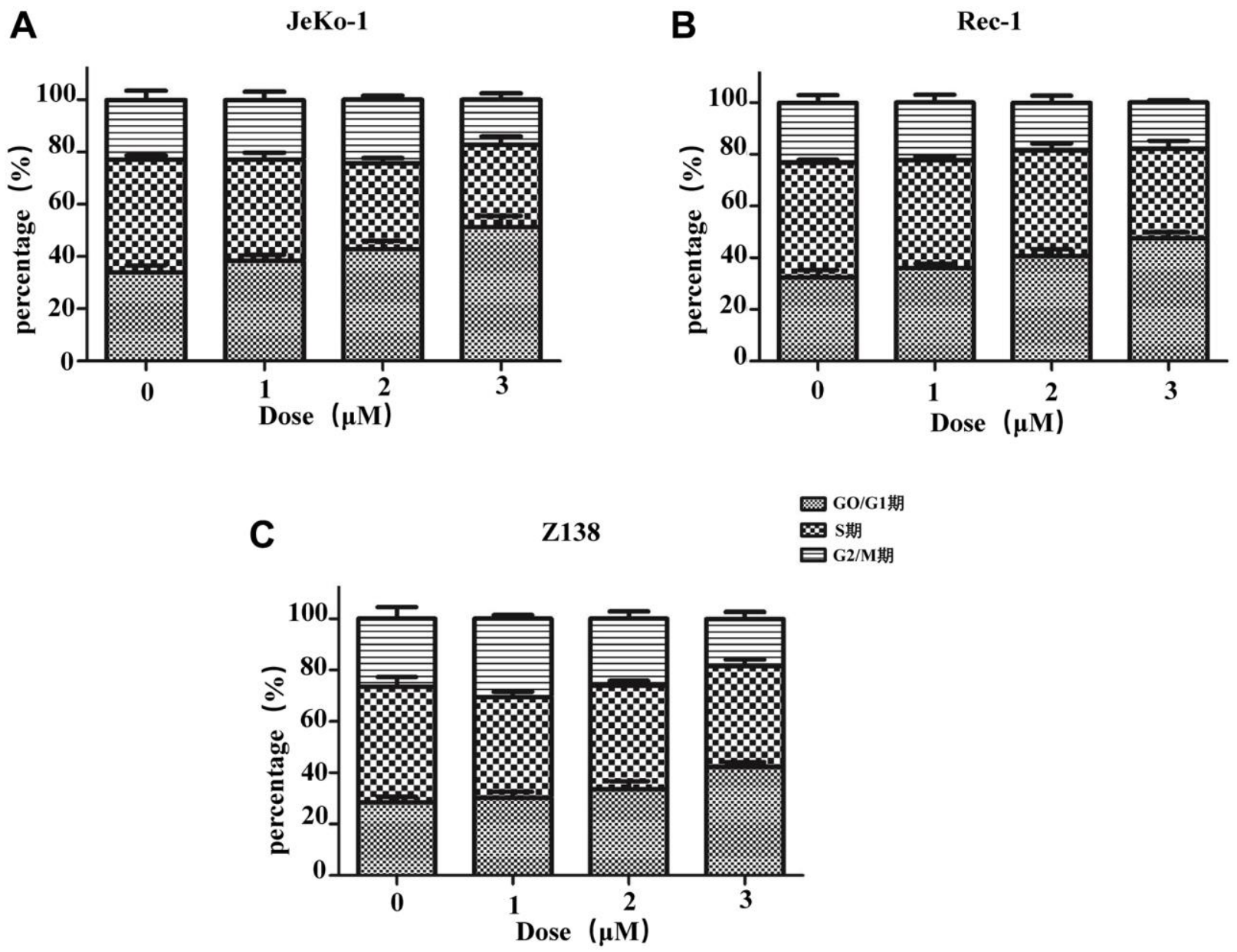

Supplementary Figure 1. Cell-cycle diagrams of Jeko-1 (A) Rec-1 (B) and Z138 (C) cells after treating with various concentrations of BGB3111 for $48 \mathrm{~h}$. The cell percentage of the cell cycle was detected by flow cytometry. 
A

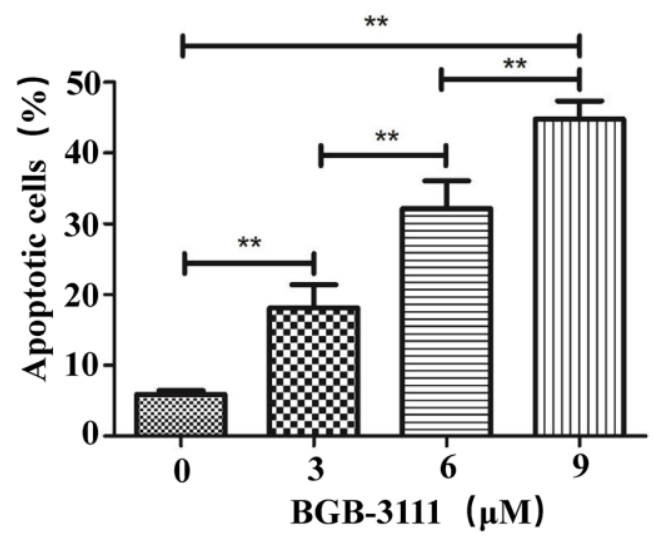

B

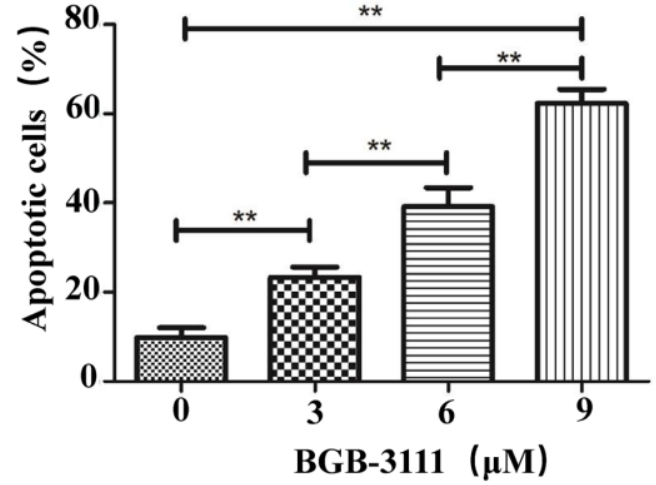

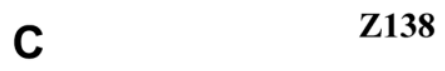

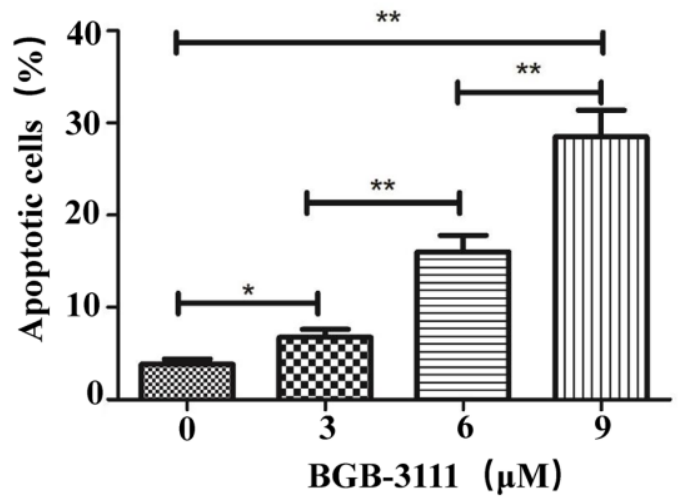

Supplementary Figure 2. Cell apoptotic distribution of Jeko-1 (A) Rec-1 (B) and Z138 (C) cells after treating with various concentrations of BGB-3111 for $48 \mathrm{~h}$. Cell apoptotic rate was detected by flow cytometric analysis. ${ }^{*} p<0.05,{ }^{* *} p<0.01$. 

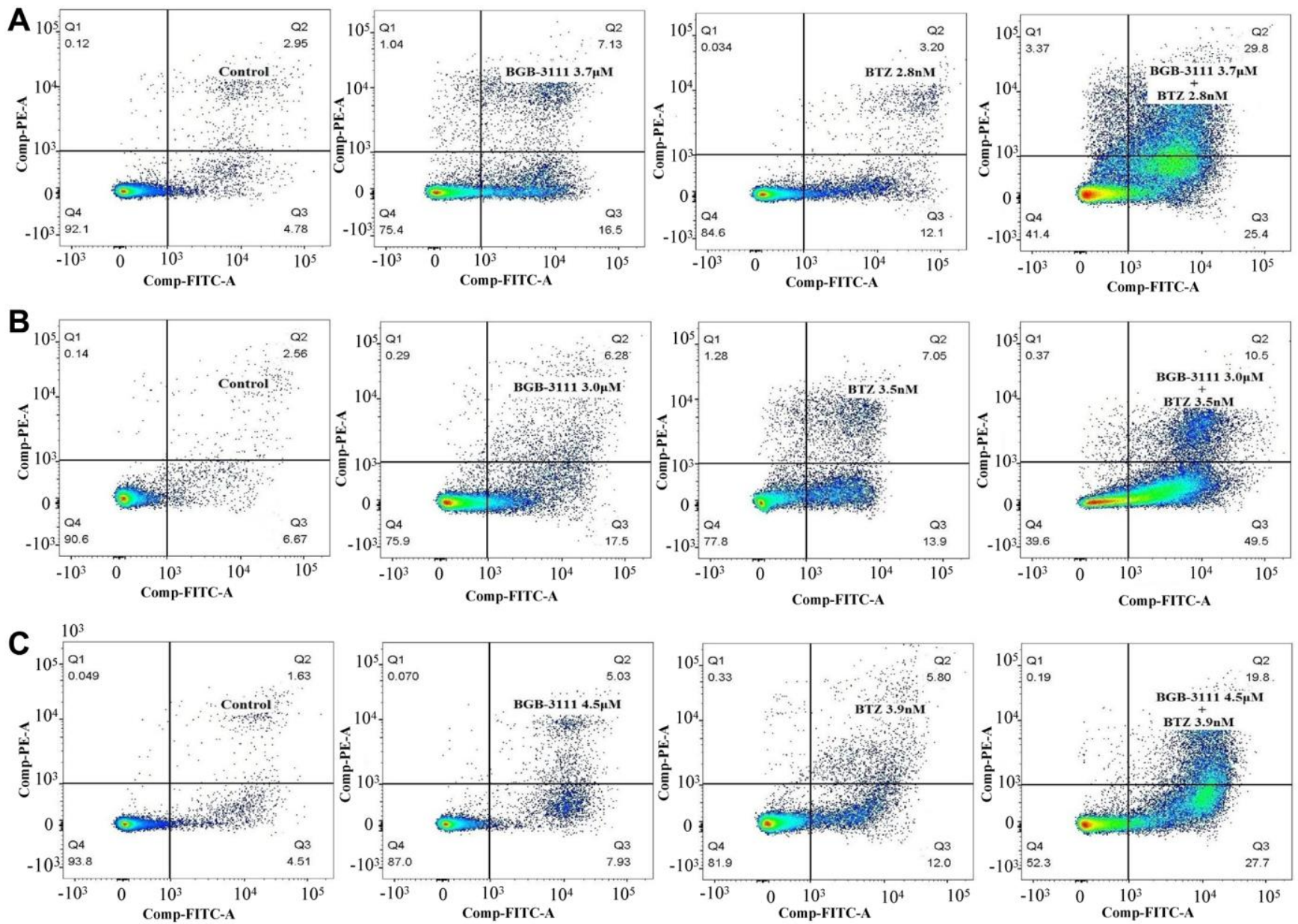

Supplementary Figure 3. Cell apoptosis in Jeko-1 (A) Rec-1 (B) and Z138 (C) cells after treating with low-dose BGB-3111, low-dose BTZ, and their combination for $48 \mathrm{~h}$. Cell apoptotic rate was detected by flow cytometry. 

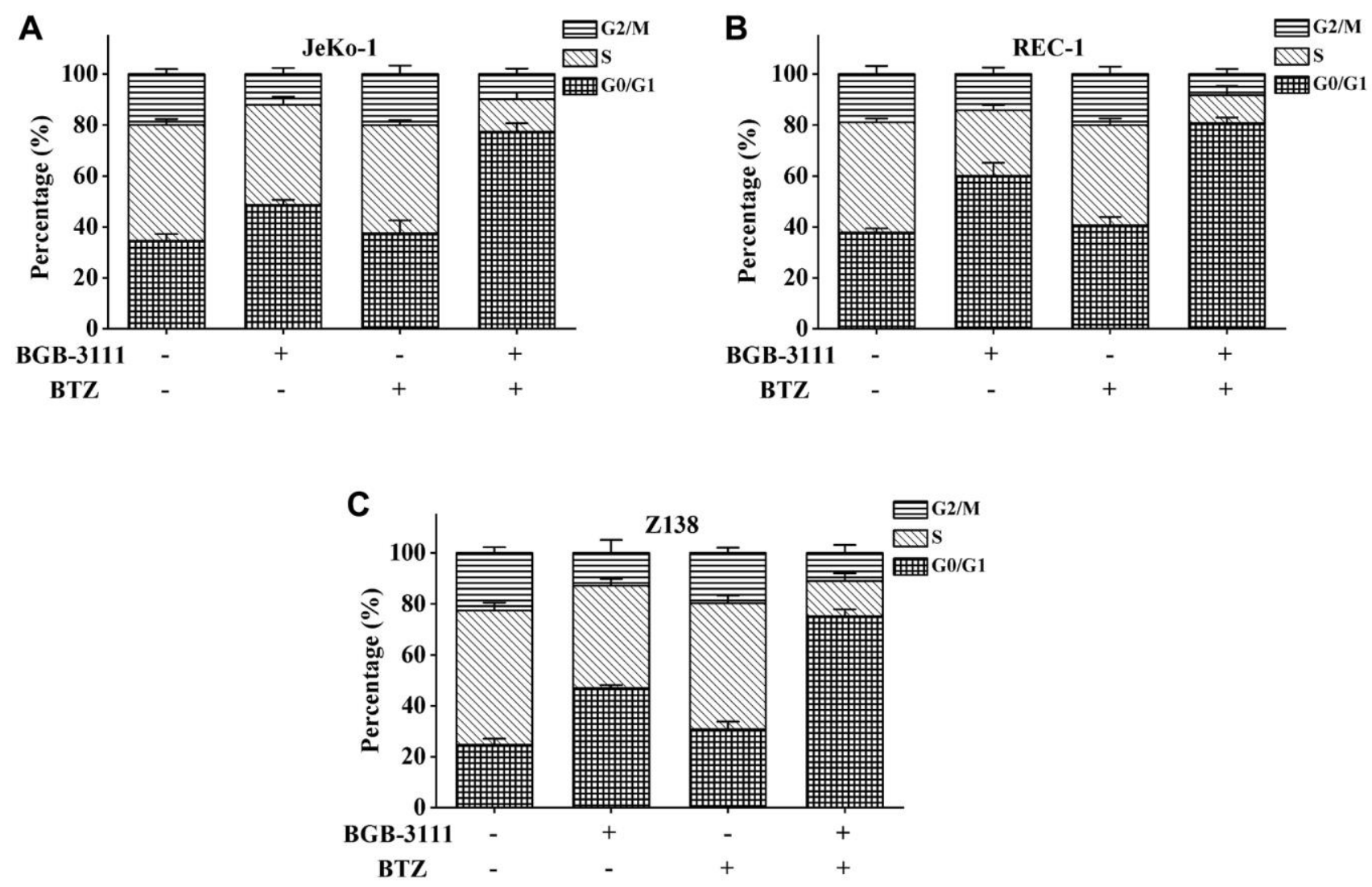

Supplementary Figure 4. Cell-cycle diagrams of Jeko-1 (A) Rec-1 (B) and Z138 (C) cells after treating with various concentrations of BGB3111 and BTZ for $48 \mathrm{~h}$. The cell percentage of the cell cycle was detected by flow cytometry. 


\section{Supplementary Table}

Supplementary Table 1. Association between BTK expression and clinicopathologic parameters.

\begin{tabular}{|c|c|c|c|c|c|}
\hline \multirow{2}{*}{ Characteristics } & \multirow{2}{*}{ Total $(n=32)$} & \multicolumn{2}{|c|}{ BTK expression } & \multirow{2}{*}{$\chi^{2}$} & \multirow{2}{*}{$P$ value } \\
\hline & & High $(n=19)$ & Low $(n=13)$ & & \\
\hline Gender & & & & 0.076 & 0.545 \\
\hline Male & $23(72 \%)$ & $14(73.7 \%)$ & $9(69.2 \%)$ & & \\
\hline Female & $9(28 \%)$ & $5(26.3)$ & $4(30.8 \%)$ & & \\
\hline Age & & & & 1.943 & 0.153 \\
\hline$<65$ & $20(63 \%)$ & $10(52.6 \%)$ & $10(76.9 \%)$ & & \\
\hline$\geq 65$ & $12(37 \%)$ & $9(47.4 \%)$ & $3(23.1 \%)$ & & \\
\hline ECOG score & & & & 4.055 & 0.058 \\
\hline $0-1$ & $27(84 \%)$ & $14(73.7 \%)$ & $13(100 \%)$ & & \\
\hline $2-4$ & $5(16 \%)$ & $5(26.3 \%)$ & $0(0 \%)$ & & \\
\hline B symptoms & & & & 0.162 & 0.487 \\
\hline No & $21(66 \%)$ & $13(68.4 \%)$ & $8(61.5 \%)$ & & \\
\hline Yes & $11(34 \%)$ & $6(31.6 \%)$ & $5(38.5 \%)$ & & \\
\hline Stage & & & & 4.838 & 0.051 \\
\hline I-II & $3(9 \%)$ & $0(0 \%)$ & $3(23.1 \%)$ & & \\
\hline III-IV & $29(91 \%)$ & $19(100 \%)$ & $10(76.9 \%)$ & & \\
\hline BM involvement & & & & 2.496 & 0.114 \\
\hline No & $12(37 \%)$ & $5(26.3 \%)$ & $7(53.8 \%)$ & & \\
\hline Yes & $20(63 \%)$ & $14(73.7 \%)$ & $6(46.2 \%)$ & & \\
\hline $\mathrm{WBC} / \mathrm{mm}$ & & & & 0.173 & 0.327 \\
\hline$<10,000$ & $21(66 \%)$ & $12(63.2 \%)$ & $9(69.2 \%)$ & & \\
\hline$\geq 10,000$ & $11(34 \%)$ & $7(36.8 \%)$ & $4(30.8 \%)$ & & \\
\hline B2-MG & & & & 0.275 & 0.521 \\
\hline$\leq 3 \mathrm{mg} / \mathrm{L}$ & $18(56 \%)$ & $8(47 \%)$ & $10(67 \%)$ & & \\
\hline$>3 \mathrm{mg} / \mathrm{L}$ & $14(44 \%)$ & $9(53 \%)$ & $5(33 \%)$ & & \\
\hline LDH/(IU/L) & & & & 0.13 & 0.5 \\
\hline$<250$ & $16(50 \%)$ & $9(47.4 \%)$ & $7(53.8 \%)$ & & \\
\hline$\geq 250$ & $16(50 \%)$ & $10(52.6 \%)$ & $6(46.2 \%)$ & & \\
\hline Ki-67 & & & & 5.783 & $0.019^{*}$ \\
\hline$\leq 30 \%$ & $19(59 \%)$ & $8(42.1 \%)$ & $11(84.6 \%)$ & & \\
\hline$>30 \%$ & $13(41 \%)$ & $11(57.9 \%)$ & $2(15.4 \%)$ & & \\
\hline MIPI score & & & & 4.522 & $0.038^{*}$ \\
\hline Low-Middle risk $(<6)$ & $23(72 \%)$ & $11(57.9 \%)$ & $12(92.3 \%)$ & & \\
\hline Middle-High risk ( $\geq 6$ ) & $9(28 \%)$ & $8(42.1 \%)$ & $1(7.7 \%)$ & & \\
\hline
\end{tabular}

